\title{
0 Gênero Andira Lam. (Leguminosae Papilionoideae) no Brasil
}

\author{
Nilza Fischer Mattos (")
}

\begin{abstract}
Resumo
A autora efetua o estudo das espécies brasileiras do gênero Andira Lam., grupo de plantas conhecidas pelo nome popular "Angelim", as quais são aqui apresentadas como uma contribuição para o melhor conhecimento do gênero. Foram encontradas 27 espécies e 7 variedades para o Brasil, sendo que o maior númera de espécies se encontra na Amazônia Brasileira. Decresce o número de espécies, à medida que sua ocorrência se aproxima do sul do País, sendo que, no Estado do Paraná, encontram-se duas espécies, uma em Santa Catarina e nenhum representante do gênero no Rio Grande do Sul. Neste trabalho, é, também, apresentada uma chave para a identificação das secçōes, subsecçöes e espécies brasileiras.
\end{abstract}

\section{INTRODUÇÃo}

O gênero Andira Lam. compreende o grupo de vegetais vulgarmente conhecido por "Angelins". É representado por mais de 30 espécies, sendo a maioria originária do Brasil.

Os "Angelins" são bastante conhecidos pelo povo, dada a sua utilização como plantas medicinais. Sua taxonomia, porém, é muito complicada. São plantas difíceis de ser estudadas sob este aspecto, face à grande variação da parte vegetativa e à inexistência de material típico das espécies, salvo em pouquíssimos casos. Como alguém deveria tentar resolver os problemas deste grupo, procuramos fazê-lo. Os resultados obtidos vão expostos no corpo deste trabalho.

A validade ou não do gênero Andira tem sido objeto de polêmica entre alguns botânicos. Certos autores acham que ơs gêneros Andria e Geoffroea devem ser reunidos novamente (pois, o primeiro foi desmembrado do segundo por Lamark, em 1783). Outros, porém, acham que devem permanecer independentes, porque ambos possuem caracteres distintos.
Macbride, em Flora do Peru (1943), reuniuos, quando sinonimizou Andira inermis e Andira surinamensis sob Geoffroea. Particularmente, não concordamos com esta sinonimização, pois, examinando material abundante de ambos os gêneros, pudemos verificar as peculiaridades de cada um. Não há dúvida de que os frutos têm alguma semelhança, porém, os caracteres vegetativos, bem como a morfologia de suas flores, têm diferenças marcantes. Andira possui ovário estipitado, com 4 a 8 óvulos; os estames são soldados até mais ou menos $2 / 3$ do androceu, sendo o vexilar livre, enquanto que em Geoffroea o ovário é séssil, com 2 a 4 óvulos e os estames são soldados em diferentes alturas do androceu, sendo, às vezes, quase livres e o vexilar sempre livre. Além destes, há, também, outros caracteres, tais como o tipo de inflorescência, a forma e a disposição dos folíolos, o aspecto do fruto, que também diferem e cujo conjunto nos faz sentir a necessidade de considerá-los gêneros independentes.

Burkart (1949-1950) declara não compartilhar da idéia de Macbride, sinonimizando Anćira sob Geoffroea, e exclui deste último gênero, Andira inermis e Andira surinamensis, que Macbride (1943) havia colocado sob Geoffroea. Ducke (1949) também menciona este fato e, apesar de reconhecer certa afinidade entre estes dois gêneros, não concorda com a sinonimização proposta por Macbride.

Pelo que acabamos de expor, parece-nos mais prudente manter-se Andira como gênero independente de Geoffroea, mesmo porque sua sinonimização não traria qualquer benefício à sistemática, pois, a sinonimizaçăo de um gênero com tantas espécies somente traria dificuldades. Por outro lado, tratando-se de espécies medicinais, será melhor conservarmos a

(*) - Instituto de Pesquisas de Recursos Naturais Renováveis da Secretaria da Agricultura, RS. Bolsista do CNPq. 
denominação já aceita e consagrada, a menos que um imperativo mais forte justificasse a aceitação de Geoffroea, incluindo Andira na sua sinonímia.

\section{HERBÁRIOS CONSULTADOS}

O material botânico estudado para a realização deste trabalho pertence aos seguintes herbários: Herbário Bradeanum, do Rio de Janeiro (HB): Herbário do Instituto de Botânica de São Paulo (SP); Herbário do Jardim Botânico do Rio de Janeiro (RB); Herbário do Museu Nacional do Rio de Janeiro $(R)$; Herbário "Barbosa Rodrigues", de Itajaí (HBR); Herbário do Museu de Munique, da Alemanha (M); Herbário do Instituto de Botânica da Academia de Ciências da U.S.S.R. (LE); Herbário do Instituto Nacional de Pesquisas da Amazônia (INPA).

Fotos do Field Museum de Chicago ( $F$. Mus. Negm).

\section{HistóRICO}

Em face das suas propriedades vermífugas, estas plantas já eram bastante divulgadas na Europa desde 1755, onde médicos e farmacêuticos de diversos países preconizavam a industrialização da casca, transformando-a em pó, com o qual procuravam obter uma droga de aplicação anti-helmíntica. Na América, também, já era conhecido este princípio medicinal dos "Angelins", porém, estavarr incluídas espécies de outros gêneros, tais como Hymenolobium, Geoffroea, Tipuana, etc. No Brasil, usavam-se as amêndoas pulverizadas, enquanto no Suriname era usada a casca pulverizada em chás para expelir os vermes.

Parece que o farmacêutico Julius, de Utrecht, foi o primeiro a possuir esta droga na Europa, segundo Brocadet (1921). Contudo, é interessante salientar que o autor acima referido conta que, no ano de 1885 , a droga caiu em descrédito dada a multiplicidade de nomes, quando, então, resolveram usar como anti-helmínticos, agentes de origem mais constante. Antiga, também, é a confusão na denominação científica deste gênero. Foi criado por Lamark em 1783, quando o destacou de Geoffroea, por considerá-lo um gênero independente.

\section{NOMES VULGARES}

As espécies de Andira são conhecidas, principalmente, pelo nome de "Angelim", em nosso País. A Andira surinamensis é connecida, na Venezuela com os nomes vulgares de "papillon" ou "sobo" (Pittier, 1944).

Vejamos a seguir, os nomes vulgares de algumas espécies de Andira conhecidas no Brasil :

Andira cuyabensis - angelim-mata-baratas Andira humilis - angelim-do-campo, angelim. amargoso.

Andira parvifolia - angelim-mata-baratas

Andira parviflora - sucupira-vermelha

Andira pisonis - angelim-pintado, angelimpenima

Andira legalis - angelim-coco, urarema

Andira vermifuga - angelim-do-campo, ange. lim-amargoso

Andira anthelmia - angelim-da-folha-larga, angelim-da-folha-grande

Andira unifoliolata - angelim-preto, pau-demorcego, sucupira-chorona

Andira fraxinifolia - angelim-doce, angelimdo-mato, mata-baratas, pinhão-do-mato, paumamona-do-mato.

Há espécies de outros gêneros que têm os mesmos nomes vulgares de "angelins", como Ferreirea spectabilis Fr. Allem. e Hymenolobium petraeum Ducke, cujo nome vulgar é "angelim-pedra"; Hymenolobium elatum Ducke, $H$. excelsum Ducke, $H$. nitidum Benth., $H$. modestum Ducke e H. pulcherrimum Ducke, conhecidos por "angelim-do-Pará"; Peraltea erythrinaefolia Sald., como "angelim-rosa", mangalô"; Vataireopsis araroba (Aguiar) Ducke, "angelim-araroba"; Platycianus regnellii Benth., "mangalô", "angelim-rosa", "pereira-vermeIha", "uba-awu", "cataguá".

\section{UTILIDADES}

As plantas conhecidas pelos nomes vulgares de "angelim" têm diversas aplicações, tanto no Brasil como noutros países. Holdridge, segundo Brocadet (1821), referindo-se à A. inermis, escreveu o seguinte: 
La semilla, asi como la corteza, se usa como laxante, vermífugo e narcótico pero en grandes dosis es un veneno activo. La madera es fuerte, durable y bastante pesada. El color varia de amarillo a castanho obscuro"... "La madera se usa en construcción general, pilotes, construcciones navales, mangos $y$ bastones.

El arbol ha sido utilizado en la isla recientemente con propositos de repoblación forestal.

Corrêa (1926) informa o seguinte, com respeito a $A$. legalis :

Fornece madeira para construção naval, obras expostas, esteios, postes, dormentes, carroçaria, tanoaria e carpintaria.

O mesmo autor ainda informa que a madeira de $A$. cuyabensis, A. paniculata, A. parvifolia, $A$. vermifuga, $A$. anthelmia, $A$. fraxinifolia e $A$. pisonis tem as mesmas aplicações que a de $A$. legalis.

Quanto à casca, é do mesmo autor acima referido as informações:

A casca e o lenho reduzidos a pó são úteis na cura de úlceras; a primeira contém o alcalóide berberina" e a glucóside "andirina" (Schoer), exala mau cheiro e dá mucilagem adocicada cujos efeitos săo purgativos, drásticos, eméticos e narcóticos". A referência acima é sobre $\mathbf{A}$. vermifuga. $\mathbf{A}$ respeiżo de $\mathbf{A}$. legalis, Corrêa cita o seguinte: "A sua casca é uma das que constituem o cortex Geoffroea das farmácias, e, ao que parece, a de efeitos terapêticos mais seguros, como vermífuga, propriedade esta, extensiva às sementes.

As folhas, também, são vermífugas, segundc este autor (1926).

As sementes são amargas e vermífugas. Porém, seu uso abusivo ou em doses elevadas é perigoso.

Todas as espécies do gênero Andira são ornamentais, podendo ser empregadas tanto nos jardins residenciais (A. laurifolia) como nos parques e avenidas. A sua folhagem é densa e bonita. Suas flores têm coloração do rosado até o violáceo.

\section{DISTRIBUIÇÃo GEOGRÁFICA}

Há cerca de 30 espécies distribuídas pela América Tropical.

No Brasil, o maior número de espécies encontra-se nos Estados de Minas Gerais e Amazonas. Para o primeiro, constatamos as seguintes espécies: Andira micans, A. fraxifolia, A. anthelmia, A. frondosa, A. paniculata,
A. vermifuga, A. laurifolia e A. surinamensis. Para o segundo, Andira villosa, A. parviflora, A. frondosa, A. macrothyrsa, A. multistipula, A. inermis, A. surinamensis, A. unifoliolata e A. micrantha. Em Mato Grosso, temos A. vermifuga, A. cuyabensis e A. inermis.

A Andira surinamensis tem uma distribuição geográfica muito ampla, pois, vai desde Minas Girais até as Guianas e Trinidad. As espécies que mais se aproximam do Sul do País são: $A$. fraxinifolia, que vai até Santa Catarina; A. anthelmia e A. laurifolia, que vão até o Estado do Pará.

No Estado de São Paulo, temos A. kuhlmannii, A. vermifuga, A. anthelmia, A. fraxinifolia, A. laurifolia, A. pisonis e A. paniculata. No Estado do Rio de Janeiro, existem muitas espécies.

\section{SISTEMÁtica DO GÊNERo Andira}

Andira Lam., Encycl. 1. 171. 1783. H.B.K., Nov. Gen. et Spec. Amer. 6: 385, 1823; DC, Prodr. 2. 475. 1825; Bentr. in Ann Wien. Mus. 2. 107. 1838; Endl., Gen. Plant. n. 6726; Ducke, Boi. Técn. Inst. Agron. Norte 18: 200. 1949; Burkart, Las Legum. Arg. 240. 1952.

Cálice campanulado, 5 - dentado, com dentes muito pequenos. Vexilo orbicular, emarginado, unha comprida, de base simples, sem apêndice; asas erectas, oblongas, base oblíqua ou algo auriculadas; pétalas carenais quase do tamanho das asas, livres, apenas com as margens dorsais sobrepostas. Estames 10 , sendo 9 unidos até mais ou menos $2 / 3$ do tamanho do androceu e o vexilar livre; anteras versáteis. Ovário longo-estipitado, oblíquo, oblongo; estilete curvo; estigma pequeno, terminal. Legume drupáceo, obovóideo ou ovóide, geralmente achatado ou ligeiramente achatado. Semente única.

Árvores ou arbustos. Casca cinzenta. Ramos terminais suberosos ou não. Estípulas persistentes ou caducas. Estipelas setáceas, rigídulas. Folhas compostas, imparipenadias. Folíolos opostos, às vezes, subopostos. Inflorescências terminais, paniculadas. Brácteas e bractéolas, geraimente, muito caducas. Flores róseas ou violáceas, subsésseis ou curto-pediceladas.

ESPÉCIE-TIPO - Andira rácemosa Lam. 
1 - Folhas com mais de 5 folíolos. Sect. Lumbricidia

2 - Ovário piloso

3 - Ovário ciliado

4 - Folíolos $9-11$, de $5-15 \mathrm{~cm}$ de comprimento, vilosos e esbranquiçados na

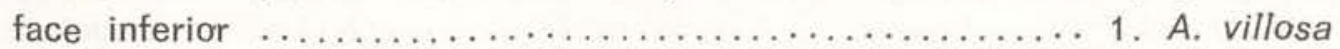

4' - Folíolos cerca de $7-9$, com $2,4-4,5 \mathrm{~cm}$ de comprimento não esbranquiçados, ovados ou ovado-obiongos, obovados ou oblongos, pubescentes na

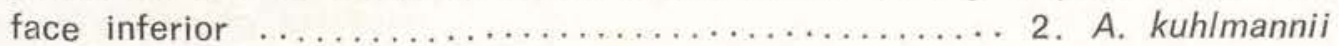

3'- Ovário esparso-piloso (não ciliado), pubescente, viloso ou tomentoso .

5 - Folhas glabras ............................ micrantha

$5^{\prime}$ - Folhas pilosas

6 - Folíolos pilosos na face inferior

7 - Estipulas resistentes, grandes com cerca de 2,2cm de comprimento. Base dos folíolos arredondada .......... 4. A. legalis

$7^{\prime}$ - Estípulas pequenas, $3-9,5 \mathrm{~mm}$ de comprimento, persistentes ou caducas. Base dos folíolos subcordada ou cordada.

8 - Panículas cinzento-amareladas. ....... 5. A. cuyabensis

8' - Panículas ferrugíneo ou ruivo-tomentosas

9 - Panículas ferrugíneo-tomentosas

10 - Folíolos $5-9$, coriáceos, oval-oblongos, com pilosidade densa na face inferior. Peciólulos de $0,2-0,4 \mathrm{~mm}$ de comprimento.

11 - Folíolos ruivo-seríceos na face inferior. Cálice com $8 \mathrm{~mm}$ de comprimento.

12 - Folíolos com ápice obtuso ou curtamente acuminado. .. 6. A. pisonis var. pisonis

12 ' - Folíclo ocm ápice emarginado .... 6a. A. pisonis var. emarginata

$11^{\prime}$ - Folíolos apenas pubérulos na face inferior Cálice com $6 \mathrm{~mm}$ de comprimento ...... ..........6. Ab. pisonis var. puberula

10' - Folíolos $9-11$, cartáceos, oblongos ou lanceados, pubescentes até quase glabros na face inferior. Peciôlulos de $1,5-3 \mathrm{~mm}$ de comprimento. 13 - Folíolos oblongos .... 7. A. fraxinifolia var. fraxinifolia

13' - Folíolos lanceados ... 7a. A. traxinifolia var. lanceata

9' - Panículas ruivo-tomentosas.

14 - Folíolos com cerca de $2,5 \mathrm{~cm}$ de comprimento, ovados; estípite ligeiramente menor que o cálice ................... 8. A. parvifolia

14 ' Folíolos com mais de $2,8 \mathrm{~cm}$ de comprimento, oblongos, obovados ou obovado-oblongos. Estípite alcançando até a metade do comprimento do cálice. 
15 - Folíolos 5 - 9. Cálice com $2-3 \mathrm{~mm}$ de comprimento ............ 9. A. parvitlora

$15^{\prime}$ - Folíolos de $9-15$. Cálice com mais de $6 \mathrm{~mm}$ de comprimento.

16 - Ramos robustos com mais de $0,5 \mathrm{~mm}$ de diâmetro. Estípulas com mais de $12 \mathrm{~mm}$ de comprimento, pubescentes.

Folíolos muito coriáceos, com nervuras muito sulcadas na face superior e muito salientes na inferior. Cálice densamente lanoso, com cerca de $8 \mathrm{~mm}$ de comprimento.

17 - Folíolos com até $10 \mathrm{~cm}$ de comprimento e até $5,5 \mathrm{~cm}$ de largura, ovalados, obovado-oblongos ou elíptico-oblongos ........... A. frondosa var. frondosa

$17^{\circ}$ - Folíolos lanceados ou sob-lan ceados, de $6-15 \mathrm{~cm}$ de comprimento e $2,4-$ $3,8 \mathrm{~cm}$ de largura .................... 10. A. frondosa var. longifoliolata

16' - Ramos com 3-4,5 mm de diâmetro, estípula 1,2-8 mm de comprimento. Folíolos cartáceos ou coriáceos; nervuras delgadas, planas ou ligeiramente impressas na face superior. Cálice pubescente, com até $6 \mathrm{~mm}$ de comprimento.

18 - Folíolos com a face superior muito brilhante e lisa; face inferior reticulada, áspera e subopaca; ápice curtamente rostrado ....... 11. A. pernambucensis

$18^{\prime}$ - Folíolos com a face superior subopaca ou brilhante, não sendo muito lisa na inferior, ápice agudo, subarredondado, subemarginado ou retuso.

19 - Folíolos com a base arredondada ou subcordada. Ápice retuso, margens planas ou ligeiramente recurvas. Estipelas com 1-1,5 mm de comprimento, às vezes, extra axilares. Face superior da lâmina, brilhante e a face inferior, amarelado-pubescente ................ 12. A. handroana

$19^{\prime}$ - Folíolos cartáceos ou coriáceos com a base, em geral, largamente cuneada ou subarredondada. Ápice agudo, subarredondado ou subemarginado; margens recurvas.

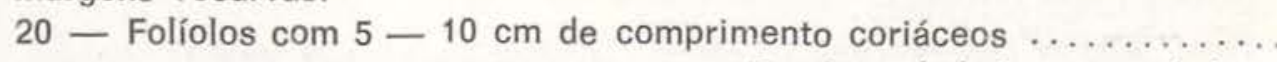
$\ldots \ldots \ldots \ldots \ldots \ldots \ldots \ldots \ldots \ldots \ldots \ldots \ldots \ldots$ 13. A. anthelmia var. anthelmia

$20^{\prime}$ - Folíolos de $1,4-5,1 \mathrm{~cm}$ de comprimento, cartáceos .......... ............................ 13a. Anthelmia var. grailis

$6^{\prime}$ - Folíolos pilosos em ambas as faces.

21 - Folíolos vilosos ou sublanosos.

22 - Folíolos (novos) lanceolados ou oblanceolados, mais ou menos esbranquiçados na face inferior e, também, nas folhas adultas, base aguda ou cunea-

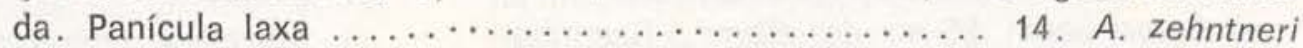

$22^{\prime}$ - Folíolos seríceos e ligeiramente brilhantes na face inferior, ovado-oblongos, base arredondada. Panículas bastante ramificadas .... 15. A. micans

$21^{\prime}$ - Folíolos glabérrimos ........................ 16. A. macrothyrsa

2'- Ovário glabro. Subsect. Glabratae

23 - Cálice glabro, às vezes, com poucos pêlos nas margens.

24 - Folíolos oblongos, obovado-oblongos ou ovado-oblongos.

Estípulas caducas e pequenas (menores que em $A$. multistipula)

25 - Folíolos ovado-oblongos, $5-9,5 \mathrm{~cm}$ de comprimento e $2,2-5,2 \mathrm{~cm}$ de largura, glabros ou glabérrimos, brilhantes nas duas faces, acuminados...

....................................... 17. nitida e 1,3-3,2 cm de largura, esparsamente adpressopilosos e opacos na face inferior, ápice emarginado ............... 18. A. marauensis

24 - Folíolos oblongo-lanceados. Estipelas numerosas, persistentes 19. A. multistipula $23^{\prime}$ - Cálice pubescente ou tomentoso.

26 - Folíolos pilosos nas duas faces. Panícula aberta e ampla .... 20. A. paniculata

$26^{\prime}$ - Folíolos glabros na face superior, pubescentes ou pubérulos na inferior, ou algumas vezes, glabros nas duas faces. 
27 - Folíolos pubescentes na face inferior, coriáceos, base subcordada, ápice obtuso, retuso ou

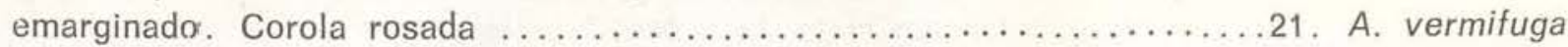

$27^{\prime}$ - Folíolos glabros nas duas faces ou apenas pubérulos na inferior. Pétalas violáceas.

28 - Folíolos glabros nas duas faces.

29 - Folíolos cordados na base .............. 22a. A. laurifolia var. cordata

$29^{\prime}$ - Folíolos não cordados na base.

30 - Arbusto, geralmente, quase acaule. Folíolos oblongos, ápice obtuso ou retuso. Cálice com cerca de $4,5 \mathrm{~mm}$ de comprimentc .. 22b. A. laurifolia var. laurifolia.

$30^{\prime}$ - Árvores com até $20 \mathrm{~m}$ de altura. Folíolos oblongos, acuminados. Cálice com $3-4 \mathrm{~mm}$ de comprimento ............... 23. A. inermis

28 ' - Folíolos pubérulos na face inferior.

31 - Ramos terminais e novos, glabros. Folíolos cartáceos ou subcoriáceos, de ápi. ce acuminado ........................ 23a. A. inermis var. riedeliana

$31^{\prime}$ - Raminhos terminais tomentosos e depois glabriúsculos. Folíolos coriáceos, de ápice obtuso, retuso ou emarginado. .............. 24. A. surinamensis

$1^{\prime}$ - Folhas com $1-3$ folíolos. Sec. Paucifoliolatae.

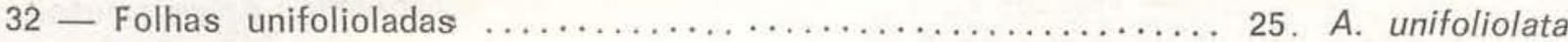

32 ' - Folhas trifolioladas ............................... 26. A. trifoliolata

Fora da chave: 27. A. bahiensis

Sect. Lumbricidia Benth., in Mart. Fl. Bras. 15(1): 292. 1862.

Unha do vexilo quase do comprimento do cálice, às vezes, superando-o.

Ovário longo-estipitado.

Tipo: Andira legalis (Vell.) Toledo (Lumbricidia legalis Vell.)

Subsect. Lumbricidia.

Ovário pubescente ou viloso.

Tipo: Andira legalis (Vell.) Toledo.

Andira villosa Kleinh., in Rec. Trav. Bot. Néerl. 22: 404. 1925 .

Árvore com $25 \mathrm{~m}$ de altura. Raminhos terminais, pecíolos e estípulas vilosas. Estípulas persistentes, com $5 \mathrm{~mm}$ de comprimento, triangulares. Folíolos 9-11, com $5-15 \mathrm{~cm}$ de comprimento e 3-6 cm de largura, oblongos, curtos e abruptamente acuminados, ligeiramente glabros na face superior e vilosos na inferior. Panículas pequenas, densamente vilosas; brácteas de $7 \mathrm{~mm}$ de comprimento, triangulares; bractéolas de $5 \mathrm{~mm}$ de comprimento, subuladas, muito decíduas; pedicelos curtíssimos. Cálice com cerca de (6-) $7 \mathrm{~mm}$ de comprimento, viloso, com dentes de (1-) $2 \mathrm{~mm}$ de comprimento. Pétalas castanhoescuras, com cerca de $8 \mathrm{~mm}$ de comprimento. Estames diadelfos. Ovário biovulado, pilosos nas suturas.

TIPO - Suriname (ex Guiana Holandesa): Pulle 319.
DISTRIBUIÇÃO GEOGRÁFICA - Suriname e norte do Brasil.

MATERIAL ESTUdAdo - BRASIL. - Estado do Amazonas: Campos de Humaitá, rio Madeira, 22-VI-1936, A. Ducke s.n. (RB 35076).

oBSERVAÇÃo - Esta espécie é assinalada aqui como nova para o Brasil.

Andira kubimannii N. Mattos, in Loefgrenia, 40:3. 1970.

(Fig. 1)

Árvore com cerca de $20 \mathrm{~m}$ de altura. Ramos cinzentos com a extremidade escura, estriados, pubescentes, com pelos cinzento-claros. Folhas com 7 folíolos; pecíolo comum pubescente, com $5,5-10 \mathrm{~cm}$ de comprimento, estriado, sulcado. Estípulas de $3-3,5 \mathrm{~mm}$ de comprimento, lineares ou lanceolado-lineares, pubescentes; lâminas de $2,4-4,5 \mathrm{~cm}$ de comprimento e $1,6-3 \mathrm{~cm}$ de largura, ovacias ou obovado-oblongas, coriáceas, glabras na 


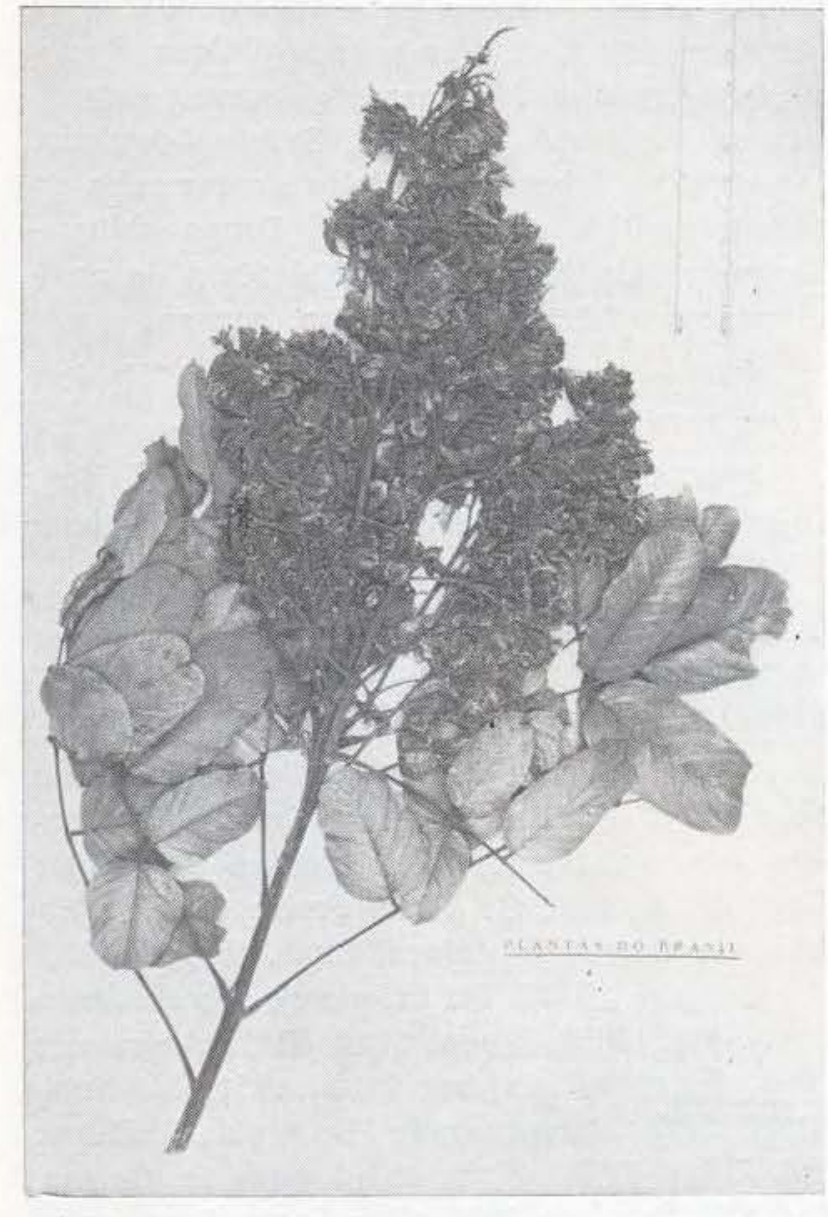

Fig 1 - Andira kuhlmannii (Holotypus)

face superior e subseríceas na inferior, ápice emarginado ou arredondado, base arredondado-subtruncada, margens recurvas; nervuras impressas na face superior e bem salientes na inferior. Panícula densa, com cerca de $20 \mathrm{~cm}$ de comprimento; pedúnculos e raque subanguloso-sulcados, pubescentes, com pilosidade ruiva. Flores com estandarte orbicular, emarginado. Cálice escuro, com pêlos seríceos, glabro apenas internamente, 5 dentado com dentes ovado-triangulares, de $1,5-2 \mathrm{~mm}$ de comprimento. Estames 10 , sendo o vexilar livre e os demais unidos até mais ou menos $2 / 3$ do comprimento do tubo estaminal; anteras oblongas, de $0,8-0,9 \mathrm{~mm}$ de comprimento. Ovário com $1,4 \mathrm{~cm}$ de com. primento, estipitado, ciliado, estilete curvo; estigma simples.

TIPO - Estado de São Paulo: Moji-Mirim margem da Rodovia para Campinas, próximo à entrada da Fazenda Holambra, 20-IX-1956 . Árvore de cerca de $20 \mathrm{~m}$ de altura, com tronco de quase $8 \mathrm{~m}$ de comprimento e $65 \mathrm{~cm}$ de diâmetro. Flores muito procuradas por abeihas. M. Kuhlmann 3945 (HB, Holotypus; SP, Isotypus); Anhembi, Fazenda Barreiro Rico, 13-11-1969. Na várzea. Frutos imaturos, M. Kuhlmann s.n. (HB, Paratypus).

Andira micrantha Ducke, in Arch. Inst. Biol. Vegetal 2:48.1938.

Arvore alta (segundo Ducke). Raminhos terminais glabros, pardo-avermelhados, ligeiramente angulosos. Folhas glabras, com $5(-7)$ folíolos; estípulas muito caducas; pecíolos de $4-7,5 \mathrm{~cm}$ de comprimento, estriados, ligeiramente canaliculados, escuros, raque estriada e ligeiramente canaliculada, também escura; peciólulos de $4-5 \mathrm{~mm}$ de comprimento, escuros, canaliculados na face superior; estipelas setáceas, com $1-3 \mathrm{~mm}$ de comprimento, lâmina dos folíolos com $5-8(-12,5) \mathrm{cm}$ de comprimento e $2-3,5(-5,6) \mathrm{cm}$ de largura, oblongo-ovaladas ou lanceolado-oblongas, cartáceo-coriáceas, castanho-escuro-esverdeadas e brihante na face superior e, castanhas e opacas na inferior, ápice acuminado, base arredondada ou arredondado-obtusa, nervura principal impressa na face superior e saliente na inferior, margens pouco venosas, nervuras secundárias subplanas na face superior., salientes e amareladas na inferior. Panículas laxas, axilares ou terminais com cerca de $12 \mathrm{~cm}$ de comprimento, ruivas, vilosas, com pedúnculos, pedicelos e raque escuros achatados e estriados. Flores pequenas. Cálice mais ou menos negro, ruivo-piloso, campanulado, com cerca de $2,5 \mathrm{~mm}$ de comprimento, com dentes largamente triangulares ou triangular-arredondados. Pétalas brancas, com cerca de $7,5-9 \mathrm{~mm}$ de comprimento, unha com cerca de $3 \mathrm{~mm}$ de comprimento. Estames de $0,8 \mathrm{~mm}$ de comprimento, concrescidos até quase $2 / 3$ do comprimento, com o vexilar livre. Ovário ruivo-tomentoso ou pilóst. lo, estipitado; estípite de $2,5 \mathrm{~mm}$ de comprimento. Drupa ovóidea, algo oblíqua e um pouco achatada, com $8 \mathrm{~cm}$ de comprimento e $6,5 \mathrm{~cm}$ de diâmetro. 
TIPO - Estado do Amazonas: ca. de Ma. naus, estrada do Aleixo, 9-V-1932, A. Ducke s.n. (RB) .

DISTRIBUIÇÃo GEOGRÁFICA - Brasil, no Estado do Amazonas.

MATERIAL ESTUDADO - BRASIL. Estado do Amazonas: cerca de Manaus, Estrada do Aleixo, 12-IV-1937, A. Ducke s.n. $(R B, R)$; idem 10-V-1932, A. Ducke s.n. (RB). Território Federal de Rondônia: Forte Príncipe da Beira. Conceição, 8-I-1962, W. Rodrigues \& B. Wilson 4273 (INPA).

Andira legalis (Vell.) Toledo var. legalis in Arq. Bot. Est. S. Paulo Nov. sér. 2(2): 20. 1946.

Lumbricidia legalis Vell., FI. Flum. Text. 305, 1825; Icon. 7: t. 105. 1831.

Andira stipulacea Benth., in Ann. Wien. Mus. 2: 107.1838.

Vouacapoua legalis (Vell.) O. Ktze., Rev, Gen. 212. 1891

Árvore de 4-6m de altura. Casca cinzenta Raminhos frutíferos mais ou menos grossos, glabros, com casca muitas vezes, suberosa. Estípulas persistentes, com 1,6-2,5cm de comprimento, largamente ovaladas, subcordadas, acuminadas, onduladas, cartilaginosas. Folhas grandes, com 11-15 folíolos; pecíolo comum incluindo a raque) de $15-45 \mathrm{~cm}$ de comprimento, estipelas setáceas, rígidas; folíolos com $5-10(-11,5) \mathrm{cm}$ de comprimento e $2,8-3,9(-4) \mathrm{cm}$ de largura, oval-oblongos, às vezes, subopostos, cartáceos, cor de canela, face superior glabra e ligeiramente brilhante e a inferior pubérula com pelos pequenos e adpressos, margens recurvas, base arredondada, ápice largamente obtuso ou arredondado, nervuras ligeiramente impressas na face superior e salientes na inferior. Panículas com até $42 \mathrm{~cm}$ de comprimento, ligeiramente ferrugíneo-tomentosa; pedicelos curtos; brácteas inferiores, $3-4,5 \mathrm{~mm}$ de comprimento, lanceoladas, as superiores pequeníssimas ou nulas; bractéolas com cerca de $1 \mathrm{~mm}$ de comprimento, caducas Cálice com $6 \mathrm{~mm}$ de comprimento, ligeiramen te seríceo-tomentoso, base curtamente atenuada, dentes curtíssimos, obtusos ou subapiculados. Pétalas com o dobro do tamanho do cálice, violáceo-claras; vexilo orbicular, emar. ginado, aberto, com a base subcordada: asas oblongas, falcadas, com a base oblíqua e subcordada; carena ligeiramente curva. Estame vexilar livre até a base. Ovário 4-ovulado, pubescente, achatado, estípite do tamanho do cálice; estilete curto, glabro. Drupa obliquamente ovóide, grande, com até $10 \mathrm{~cm}$ de comprimentơ e $7,5 \mathrm{~cm}$ de diâmetro, rugosa.

TIPO - Estado do Rio de Janeiro: "Habitat silvis maritimis"; Vellozo.

NOMES VULGARES - "Angelim-coco", seg. Toledo (1946); "Angelim-doce" seg. Bentham (1862) .

DISTRIBUIÇÃo GEOGRÁFICA - Brasil, nos Estados da Bahia e Rio de Janeiro, seg. Bentham (1862): Estados do Espírito Santo e Ceará.

MATERIAL ESTUDADO - BRASIL - Estado do Espirito Santo: Colatina, Estrada do Pancas, 19.IV.1930, J. G. Kuhlmann 360 (RB); Bananal, X.1924, C. Viana Freire 66 (R); $k s-$ tado do Ceará: Fortaleza, São João, XI.1929. A. Lutz s.n. (R67691); Estado do Rio de Janeiro: s. loc., 1832, Riedel 1124 (RB); Angra dos Reis, Fazenda Japuyba, 21.III.1951, M. Kuhlmann 2663 (SP); Andrade Pinto, s.d., A. Ducke s.n. ( R 26957); Campos, Lagoa de Cuicas, III. 1939, Sampaio 7952 (R); Santa Cruz, entre Córrego e o Seco de Goitacazes, 9.XI.1943, J. G. Kuhlmann 6410 (RB); Sertão de Cacimbas, margem direita do Rio Itabapoan, 29.X.1909, Sampaio s.n. (R); Engenho Novo, s.d., Glaziou s.n. (R 67634); Ipanema, Lagoa Rodrigo de Freitas, 3.IX.1939, J. G. Kuhlmann s.n. (RB 40590); Restinga de Jacarepaguá, 10.IV.1958, Edmundo Pereira, Liene, Sucre \& Duarte (RB, HB); Estado da Bahia: Rodovia Marau-Ubaitaba, 6.X.1955, R. P. Belém 1879 (UB) .

Andira legalis (Vell.) Toledo var. bahiensis (Benth.) N. Mattos, in: Loefgrenia 40:3. 1970 .

A. stipulacea Benth. var. bahiensis Benth., in Mart. FI. Bras, 15(1) : 292, 1862.

Esta variedade difere da típica por ter as estípulas bem menores.

TIPO - Não indicado.

NOMES VULGares - "Angelim coco" ou "Urarema". 
DISTRIBUIÇÃo GEOGRÁFICA - Estados da Bahia e do Rio de Janeiro.

MATERIAL ESTUDADO - BRASIL - Engenho Novo, s.d., s. col., ex herb. J. de Saldanha (R 67034).

Andira cuyabensis Benth., in Mart. Fl. Bras. 15(1): 295.1862.

Andira lanei N. Mattos, in Loefgrenia 40:1. 1970 (Tipo: Fr. Lane s.n.).

Arbusto ou pequena árvore de mais ou menos $5 \mathrm{~m}$. Ramos grossos e cilíndricos; raminhos novos cilíndricos, grossos, com $5-6 \mathrm{~mm}$ de diâmetro, tomentosos. Folhas com 5-9 folíolos; estípulas e estipelas caducas; raque. pecíolo, peciólulo, face inferior dos folíolos e inflorescências pubescentes e cinzento-amarelados; conjunto de pecíolo e raque com cerca de $12(-14,5) \mathrm{cm}$ de comprimento, pecíolos com $1,5-4 \mathrm{~cm}$ de comprimento, $1,5-2 \mathrm{~mm}$ de diâmetro e subcilíndricos; folíolos com $3,8-5(-8,5) \mathrm{cm}$ de comprimento e $2,5-3,7(-4,5) \mathrm{cm}$ de largura, coriáceos, ovados, ovado-elípticos ou subobovado-oblongos, base cordada, ápice obtuso, arredondado ou ligeiramente obtuso-emarginado brilhantes e glabros (apenas com pêlos esparsos sobre a nervura principal) na face superior e cinzento-amarelados na inferior, margens recurvas; nervuras impressas na face superior e salientes na inferior. Peciólulos com $1-3 \mathrm{~mm}$ de comprimento. Panícula terminal, com $16,5-22,5(-35) \mathrm{cm}$ de comprimento multiflora, tomentosa, amarelada ou ligeiramente ruiva. Flores pequenas com $7-8 \mathrm{~mm}$ de comprimento, sésseis. Brácteas de $1-2,1 \mathrm{~mm}$ de comprimento, caducas, ovadas, avadooblongas ou lanceado-ovadas, densamente pubescentes na face externa. Cálice 5-dentado, campanulado, com $3,5 \mathrm{~mm}$ de comprimento, adpresso-seríceo-piloso, com dentes largamente triangulares. Corola glabra com $6,5-7 \mathrm{~mm}$ de comprimento. Estames com cerca de $2 / 3$ concrescidos, sendo um livre desde a base. Ovário longo-estipitado, amarelado-seríceo-piloso, biovulado; estilete curvo; estigma capitado.

TIPO - " in prov. Goyazensi prope Ourofino. secundum Rio Urubú: Pohl".

NOME VULGAR - "Mata-baratas", seg. Lane (1968).
DISTRIBUIÇÃo GEOGRÁFICA - Brasil, no Estado do Mato Grosso; Goiás, seg. Bentham (1862).

MATERIAL ESTUDADO - BRASIL - Estado do Mato Grosso: Três lagoas, Canaã, II.1969, Frederico Lane s.n. (tipo de A. lanei, SP); Brasilia-Acre Highway, $100 \mathrm{~km}$ north of Cuiabá, in route to Diamantina, $200-400 \mathrm{~m}$ de altura, August 29, 1963, Basset Maguire, J. Murça Pires, Celia K. Maguire \& Nilo T. Silva 56394 (NY, UB)

Andira pisonis Mart. ex Benth., in Ann. Wien. Mus. 2: 108. 1838; Benth. in Mart. FI. Bras. 15(2): 294, t. 3. 1862.

Árvore de $3-6 \mathrm{~m}$ de altura. Ramos mais ou menos sulcados com cerca de $3,5 \mathrm{~mm}$ de diâmetro, amarelo-claros, com pilosidade ferrugínea; ramos novos sulcados e ferrugíneos. FoIhas alternas ou subopostas; pecíolo delgado, com cerca de $1 \mathrm{~mm}$ de diâmetro; pecíolo, raque e peciólulos ferrugíneo-tomentosos; raque de $5,7-10,3 \mathrm{~cm}$ de comprimento; estípulas pequenas ou nulas (porém, no material $\mathrm{J}$. Mattos 15430, as estípulas tem cerca de $4 \mathrm{~mm}$ de comprimento), estipelas lineares com até $5 \mathrm{~mm}$; foliolos 5-9(-11) com 4,6-6,1 (-6,5) cm de comprimento e $0,45-1,9(-2,7) \mathrm{cm}$ de largura, ovados ou oblongos, coriáceos, glabros na face superior e ruivo-seríceos na inferior; base arredondada ou subobtusa, ápice obtuso ou ligeiramente acuminado; nervura principal robusta, muito impressa na face superior e saliente na inferior, nervuras secundárias cerca de 10 pares, impressas na face superior e salientes na inferior; peciólulos de $2-4 \mathrm{~mm}$ de comprimento. Panícula com cerca de $15 \mathrm{~cm}$ de comprimento, tomentosas; bractéolas caducas, com $2 \mathrm{~mm}$ de comprimento, lanceolado-lineares, tomentosas; bractéolas caducas, com $2 \mathrm{~mm}$ de comprimento, curto e densamente seríceo, com 1-1,5mm de comprimento, mais ou menos triangulares. Corola com cerca de $1,4 \mathrm{~cm}$ de comprimento. Ovário viloso. Frutos oblongos com cerca de $3,5 \mathrm{~cm}$ de comprimento e $2,5 \mathrm{~cm}$ de diâmetro.

TIPO - ... "prov. Minarum orientali inter virgulta in arenosis ad Mucuri": Martius (M).

NOME VULGAR - "Angelim-da-beira-d'água" 
DISTRIBUIÇÃo GEOGRÁFICA - Brasil, nos Estados de Minas Gerais e Bahia (seg. Benth. 1862): Rio de Janeiro e São Paulo.

OBSERVAÇÕES - Esta espécie vegeta, principalmente, à margem de riachos. É uma espécie muito afim de $A$. fraxinifolia, da qual difere, essencialmente pela consistência coriácea dos folíolos, pilosidade ruivo-serícea na página inferior dos folíolos e panículas meno. res. O material J. Mattos 15430, apresenta folíoios mais coriáceos, nervuras mais impressas na face superior, estípulas, 'estipelas e brácteas maiores que no material de Blanchet 3672, citado na Flora Brasiliensis.

MATERIAL ESTUDADO - BRASIL - Cultivada no Horto Florestal, 29.IX.1927, J. G. Kuhlman n528 (RB); Estado do Rio de Janeiro: Rio de Janeiro, Gávea, s.d. E. Ule 57 (R); idem, 1880, Glaziou 11897 (LE); s. loc., s.d., Langsdorff et Riedel 648 (LE); s. loc., 8.IX.1923, Riedel 40 (LE); idem, Glaziou 7600 (LE). Estado de São Paulo: Campinas, XII.1894, Camros Novaes 304, Ex. Comm. Geogr. Geol. São Paulo 3014 (SP). Estado da Bahia: Jacobina, s.d., Blanchet 3672 (LE).

Andira pisonis Mart. var. emarginata N. Mattos, Loefgrenia 58:2. 1973.

Difere da típica por ter o ápice dos folíolos emarginado.

TIPOS - BRASIL - Estado da Bahia: llhéus, Pontal, 3.VII.1944, Henrique P. Veloso 1001 (R, Holotypus); Iguaçu, 30.XII.1922; P. Campos Porto s.n. (RB, Paratypus). Bahia.

IISTRIBUIÇÃo GEOGRÁFICA - No Estado da

Andira pisonis Mart. var. puberula N. Mattos, Loefgrenia 58: 2. 1973.

Esta variedade apresenta folíolos com $1,6-5,8 \mathrm{~cm}$ de comprimento e $0,6-2,4 \mathrm{~cm}$ de largura, apenas pubérulos na face inferior; cálice com cerca de $6 \mathrm{~mm}$ de comprimento.

'TIPC - Espírito Santo; Iinhares, lagoa do Durão, rio Doce, IV.1934, J. G. Kuhlmann 163 (RB, Holotypus) .
DISTRIBUIÇÃo GEOGRÁFICA - Nos Estados de Minas Gerais, Espírito Santo e Rio de Janeiro.

MATERIAL ESTUdAdo - BRASIL Estado do Espirito Santo: Linhares lagoa do Durão, rio Doce, 11.IV.1934, J. G. Kuhlmann 172 (RB); Estado do Rio de Janeiro: Cabo Frio, X.1899, R. Ule s.n. (R); Estado de Minas Gerais: Diamantina, serra dos Cristais, 6.X.1937, Mello Barreto 9548 (SP).

Andira fraxinifolia Benth. var. fraxinifolia, in Ann. Wien. Mus. 2: 108. 1838.

Árvore pequena, com cerca de $3 \mathrm{~m}$ de altura, raramente atingindo porte mais elevado $(15 \mathrm{~m})$. Ramos novos ferrugíneos, mais ou menos tomentosos, logo quase glabros, subsulcados; estípulas com até $6 \mathrm{~mm}$ ou nulas, escuras e lanceolado-lineares, pilosas; estipelas setáceas, de $1-5 \mathrm{~mm}$ de comprimento. FoIhas alternas ou subopostas, de 9-11 foliolos $(-15)$, pecíolos de $3,5-8 \mathrm{~cm}$ de comprimento, com cerca de $2 \mathrm{~mm}$ de diâmetro, glabros ou pubérulos; raque mais ou menos sulcada com até $22,5 \mathrm{~cm}$ de comprimento; peciólulos robustos de $1,5-3 \mathrm{~mm}$ de comprimento e $1,5-1,9(-2,7)$ $\mathrm{cm}$ de largura, oblongos, ovado-oblongos ou lanceados, cartáceos ou rígido-cartáceos, glabros e opacos na face superior e pubescentes ou ligeiramente glabros, posteriormente, na face inferior, base subarredondada ou obtusa, ápice curto-acuminado, margens ligeiramente recurvas, nervura principal impressa na face superior e saliente na inferior. Panícula laxa, multiflora, com $15(-18) \mathrm{cm}$ de comprimento, ligeiramente tomentosa, mais ou menos ruiva; brácteas com cerca de $4 \mathrm{~mm}$. Cálice com $4,5-5 \mathrm{~cm}$ de comprimento, base obtusa, densamente adpresso-piloso, com pilosidade amarelada, dentes com cerca de $1 \mathrm{~mm}$ de comprimento e mais ou menos triangulares. Corola com cerca de $10 \mathrm{~mm}$ de comprimento. Ovário seríceo, viloso, com estipe curto. Fruto ovado-oblongo, com superfície áspera.

TIPO - Não indicado.

NOME VULGAR - "Angelim-doce".

DISTRIBUição GEOGRÁFICA - Brasil, de Minas Gerais até Santa Catarina. 
MATERIAL ESTUDADO - BRASIL - Estado de São Paulo: Salesópolis, Estação Biológica de Boracéia, perto do Rio Coruja, 26.VIII.1966, J. Mattos 13879 (SP); São Paulo, Vila Mariana, 6.X.1907, A. Usteri s.n. (SP). Estado do Paraná: Jacareí, 17.X.1931, Curgel 1648 (RB); Guaratuba, Alto da Serra, 21.XI.1959, G. Hatschbach 6513 (HB). Estado de Santa Catarina: Brusque, Mata do Hofmann, 18.X.1949, R. Klein 208 (HBR. HB) . Estado do Rio de Janeiro: Ilha do Governador, próximo de Tubaicanga, lado norte da ilha, 6.X.1963, Luiz Fernando Pabst s.n. (HB 27980). Estado de Minas Gerais: Diamantina, Rio Prata, 1.VI.1955, Edmundo Pereira 1673 (RB).

Andira fraxinifolia Benth. var. lanceata N. Mattos, Loefgrenia 57: 2. 1973.

Esta variedade difere da típica por ter folíolos lanceados menores, com $3-6,8 \mathrm{~cm}$ de comprimento e $0,8-1,4 \mathrm{~cm}$ de largura.

TIPO - BRASIL - Estado de São Paulo: $1 \mathrm{~km}$ ao norte de Atibáia, 24.IX.1963, J. Mattos 8383 N. Mattos (SP, Holotypus).

DISTRIBUIÇÃo GEOGRÁFICA - Estado de São Paulo.

Andira parvifolia Mart. ex Benth., in Ann. Wien. Mus. 2: 108. 1838.

Árvore com ramos terminais acinzentados. Estipulas subuladas ou nulas; estipelas com $2,5 \mathrm{~mm}$ de comprimento, lineares. Folhas com até 9 folíolos pequenos; pecíolos com 2,5-3.7cm de comprimento e $0,8 \mathrm{~mm}$ de diâmetro; pecíolo, raque e peciólulos pubescentes; raque de $5-7,5 \mathrm{~cm}$ de comprimento, peciólulos com $2 \mathrm{~mm}$ de comprimento; lâminas com $(2,1-) 2,5(-4) \mathrm{cm}$ de comprimento, $1,2-2,3 \mathrm{~cm}$ de largura, glabras na face superior, pubescentes ou quase glabras na inferior, cartáceas, ovadas ou suborbiculares, base arredondada ou largamente obtusa, ápice subobtuso, subarredondado ou emarginado, nervura principal impressa na face superior e saliente na inferior, nervuras secundárias muito delgadas, mais ou menos planas na face superior e salientes na inferior. Panículas curtas, com $7,5(-13) \mathrm{cm}$ de comprimento, mais ou menos ruivas com to- mento curto e adpresso; pedúnculo e raque sulcados; pedicelos de $1-3 \mathrm{~mm}$ de comprimento; bractéolas com cerca de $2 \mathrm{~mm}$ de comprimento, caducas, lineares e extremamente pilosas. Cálice com $4,5 \mathrm{~mm}$ de comprimento, acinzentado, com pilosidade curta, densa e adpressa. Ovário viloso; estípite pouco menor que o cálice. Corola com cerca de $1 \mathrm{~cm}$ de comprimento, rósea.

TIPO - "In campis altis Cerro Frio, província de Minas Gerais; Martius" (M).

DISTRIBUIÇÃo GEOGRÁFICA - Brasil, no Estado de Minas Gerais (segundo Bentham, 1862) .

MATERIAL ESTUDADO - BRASIL - Vila Nova, 21.XI.1882, Schwacke s.n. (R. 65865). Estado do Rio de Janeiro: Rio de Janeiro, 1882, Glaziou 13684 (LE). Estado de São Paulo: Perto de Sorocaba e Itu, XII.1825, Riedel 125 (LE).

Andira parviflora Ducke, in Arch. Inst. Biol. Veg. $2(1): 47.1835$

Árvore com ramos novos ruivos e hirtos, sendo os velhos grabriúsculos e cinzentos. Estípulas muito caducas. Folhas com pecíolo e raque estreitamente canaliculados na face superior, ruivos e densamente hirsutos; estipelas pequenas, setáceas; foliolos 5-9, com peciólulos curtíssimos, grossos, ruivos e hirtos; lâminas dos folíolos muito variáveis, geralmente, com $3-9 \mathrm{~cm}$ de comprimento e $1,5-3,5 \mathrm{~cm}$ de largura, muitas vezes, obovadooblongas, bastante rígido-coriáceas, glaucas, brilhantes e glabras na face superior, exceto sobre a nervura principal; ruivas e hirtas na face inferior, base estreitamente arredondada ou obtusa, ápice obtuso, agudo ou curtamente acuminado, margens recurvas; nervura principal e secundárias estreitamente impressas na face superior e grossamente salientes na inferior; vênulas densamente reticuladas na face inferior. Panículas, geralmente, terminais, densamente vilosas, ruivas, curtas ou com mais de $10 \mathrm{~cm}$ de comprimento, densifloras; brácteas pequenas, subuladas, vilosas. Flores sésseis. Cálice com 2-3mm de comprimento e largamente turbinado, com lobos largos e pouco aparentes, cinzentos e moderadamente 
pilosos, quando vivos atro-violáceos. Pétalas com 5-6mm de comprimento, glabras, ovadas com vexilo violáceo mas negruscas quando secas, com as margens claras. Estames com $9 \mathrm{~mm}$ de comprimento, concrescidos, sendo o décimo livre. Ovário curto, densamente piloso; estípite curto; estilete glabro. Drupa $4-4,5 \mathrm{~cm}$ de comprimento e $3,5-4,5 \mathrm{~cm}$ de largura, ovóidea, pouco oblíqua, apenas compressa, glabra, endocarpo pouco rugoso.

TIPo - Estado do Amazonas, ca. de Manaus, Estrada do Aleixo, 22.IV.1932, A. Ducke, s.n. (RB 23865).

DISTRIBUiçÃo GEOGRÁfICA - Brasil, no Estado do Amazonas.

MATERIAL ESTUdAdo - BRASIL - Estado do Amazonas: rio Tarumã, mata de terra firme, perto da cachoeira Alta, 22.XI.1949, A. Ducke s. n. (RB); Entre as duas cachoeiras do Tarumã, 25.IV.1932, A. Ducke s.n. (RB); Estrada Manaus-Itacoatiara, km 27, Reserva Florestal Ducke, 27. VIII.1968, J. Aluísio 115 (INPA); idem, km 85, 24.IV.1968, W. Rodrigues 8484 (INPA); idem, Estrada Manaus-Caracarí, km 30, 18.V.1972, M.F. Sliva \& Izonete 191 (INPA).

\section{Andira frondosa Mart., in Walp. 1:803. 1842.}

Árvore de copa densa. Estípulas largas, ovado-oblongas, coriáceas, persistentes. Folíolos $11-15$, às vezes, até 17 , de até $10 \mathrm{~cm}$ de comprimento e $5,5 \mathrm{~cm}$ de largura, ovalados, obovado-oblongos ou elíptico-oblongos, coriáceos, glabros na face superior e pubérulos na inferior, ápice obtuso, base obtusa, nervuras muito salientes na face inferior. Panículas axilares, ruivo-vilosas. Flores violáceas. Brácteas com $6-9,5 \mathrm{~mm}$ de comprimento, persistentes, lanceoladas, côncavas; bractéolas com $4,5 \mathrm{~mm}$ de comprimento, às vezes, até com $6 \mathrm{~mm}$ de comprimento, persistentes, lanceoladas. Cálice de $8-9 \mathrm{~mm}$ de comprimento, achatado, ruivo-viloso; dentes desiguais, com cerca de $1 \mathrm{~mm}$ de comprimento, os 4 superiores largamente arredondados e o inferior agudo. Pétalas violáceas, com quase o dobro do tamanho do cálice. Estame vexilar livre desde a base. Ovário pubescente, principalmente nas suturas, muitas vezes, quase glabros nos lados; estípite algo menor que o cálice; óvulus, 4 .

TIPO - ... "in Brasilia ad Cabo Frio in silvarum arenosis et alibi in Brasiliae orientalis maritimam: Martius" (M)

DISTRIBUIÇÃo GEOGRÁFICA - Brasil, nos Estados de Minas Gerais, Bahia e Rio de Janeiro.

MATERIAL ESTUDADO - BRASIL - Pandiá Calógeras, Fazenda São José, 8.XI.1938, J. G. Kuhlmann s.ri. (RB). Estado do Rio de Janeiro: Rio de Janeiro, Gávea, s.d. ,Ule s.n. (RB); G. Portela, Monte Sinai, s.d., G. Machado Nunes 324 (RB); Serra dos Órgãos, Barreira de Soberba, s. d., Henrique José Dias s.n. (R); Restinga de Jacarepaguá, 23.IX.1958, E. Pereira 4306, Liene, Sucre \& Duarte (RB); idem, E. Pereira 4300, Liene, Sucre \& Duarte (HB). Estado de Minas Gerais: Patos de Minas, 1950. A. Duarte 4263 (RB); Rio Doce, 23.XI.1943, J. G. Kuhlmann 6529 (RB). Estado de Pernambuco: Recife, Dois irmãos, 12.XI.1951, Dárdano de Andrade Lima 51-944 (RB, SP) . Estado da Bahia: Marau, 5.XI.1965, R. P. Belém 1830 (UB).

Andira frondosa Mart. var. Iongifoliolata N. Mattos, in Loefgrenia 57: 2. 1973.

Difere da típica por ter folíolos lanceolados ou ob-lanceados, com $6-15 \mathrm{~cm}$ de comprimento e $2,4-3,8 \mathrm{~cm}$ de largura.

TIPO - BRASIL - Estado do Rio de Janeiro: Restinga de Jacarepaguá, 23.IX.1958, Edmundo Pereira 4311, Liene, Sucre \& Duarte (HB) .

DISTRIBUIÇÃo GEOGRÁfICA - Conhecida somente da localidade típica.

Andira pernambucensis N. Mattos, Loefgrenia 53:1. 1971.

(Fig. 2)

Ramos novos, gemas, pecíolo, raque e inflorescência pubescentes com pilosidades adpresso-serícea. Ramos terminais subcilíndricos, com a extremidade ferrugínea. Folhas superiores mais ou menos oblongas, 9-folioladas, peciolo e raque sulcados e escuros, 


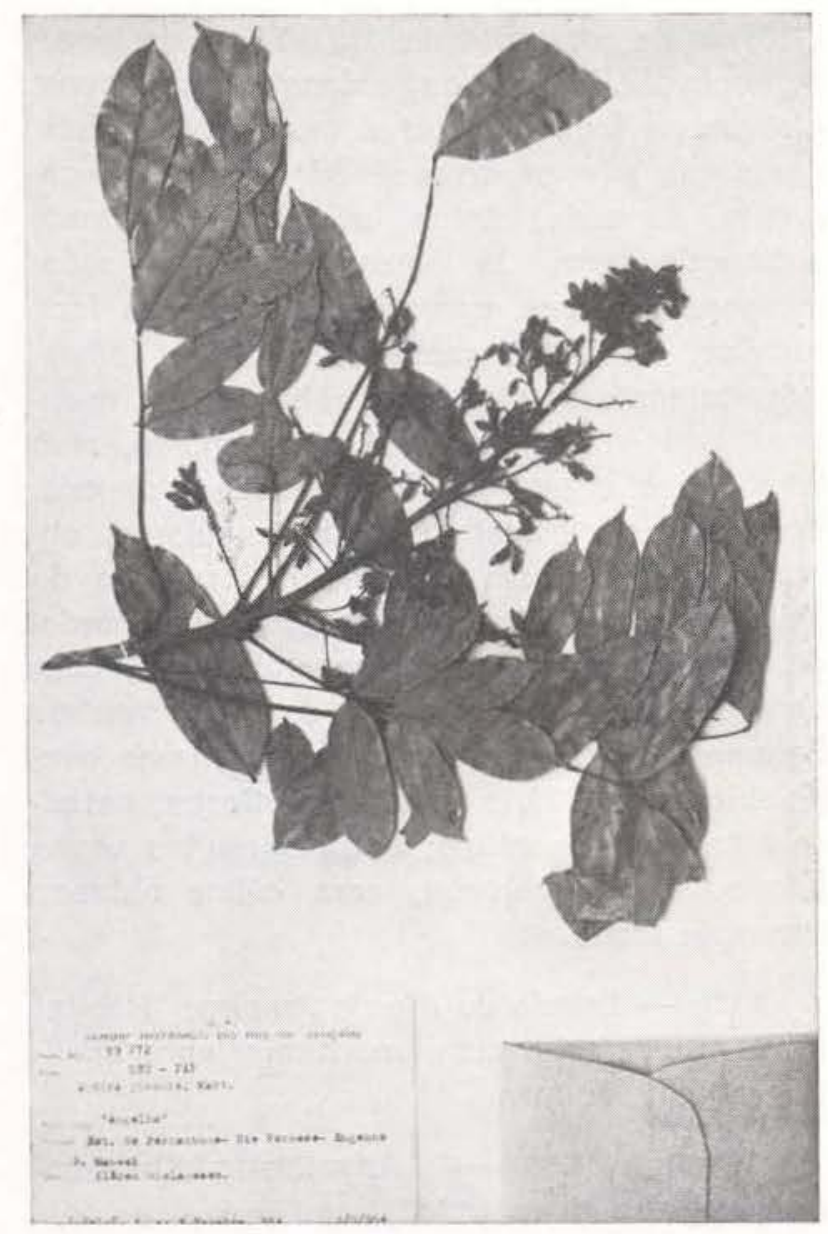

Fig. 2 - Andira pernambucensis. (RB 89272)

1-2mm de diâmetro; estipelas lineares, com $1-1,5 \mathrm{~mm}$ de comprimento; pecíolo com $4,5-9 \mathrm{~mm}$ de comprimento; raque com $6-13 \mathrm{~cm}$ de comprimento; folíolos com $2,7-9 \mathrm{~cm}$ de comprimento; $1,3-3,4 \mathrm{~cm}$ de largura, cartáceo-coriáceos, oblongos, ovado-oblongos, glabros, lisos e brilhantes na face superior, opacos e esparso-adpresso-piloso na face inferior, base obtusa ou arredondada, ápice curtamente rostrado e mais ou menos retorcido, nervuras delgadas, impressas na face superior e salientes na inferior; peciólulos com $2 \mathrm{~mm}$ de comprimento. Panículas com até $18 \mathrm{~cm}$ de comprimento, irregularmente anguladas, ferrugíneas; pedicelos de $1-3 \mathrm{~mm}$ de comprimento. Cálice adpresso-piloso com $6 \mathrm{~mm}$ de comprimento, campanulado. Pétalas violáceas (seg. coletor). Estame vexilar livre. Ovário densamente pubescente, com pilosidade adpressa; estilete glabro.
TIPO - BRASIL - Estado de Pernambuco: Formoso, Engenho São Manuel, 3-IX-1954, J. Falcão, Egler \& E. Pereira 944 (RB).

DISTRIBUIÇÃo GEOGRÁFICA - Conhecida apenas da localidade típica.

Andira handroana N. Mattos, in Loefgrenia 40: 2. 1970 ,

(Fig. 3)

Arbusto. Raminhos com cerca de $4 \mathrm{~mm}$ de diâmetro, esbranquiçados. Folhas 11-folioladas; pecíolos com até $3-3,8 \mathrm{~cm}$ de comprimentơ e $1,5 \mathrm{~mm}$ de diâmetro, glabros quando adultos; raque com $5-9 \mathrm{~cm}$ de comprimento; estipelas axilares ou extra-axilares, coriáceas, lineares, de 1-2mm de comprimento; peciólulos de 2-3mm de comprimento, sulcados na face superior; folíolos opostos ou alternos, de $2,8-5,6 \mathrm{~cm}$ de comprimento e $1,5-2,7 \mathrm{~cm}$ de lar-

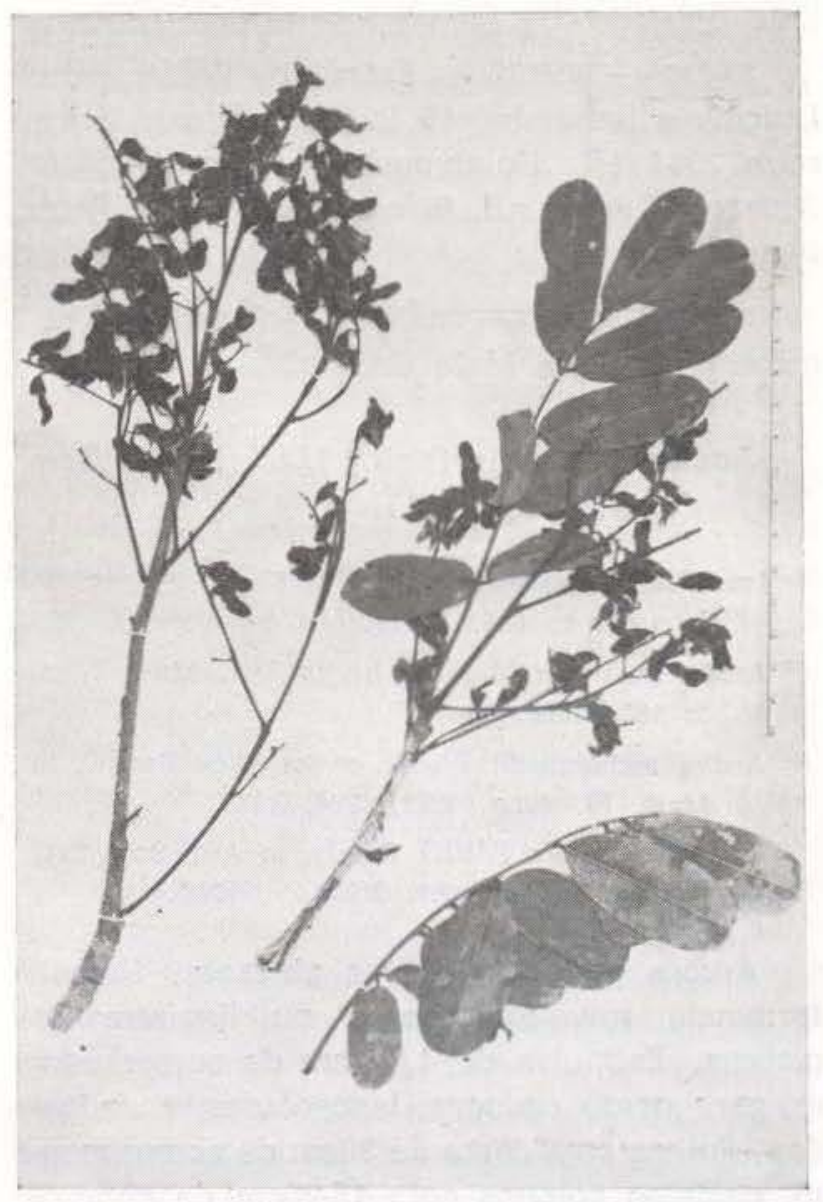

Fig. 3-Andira handroana. E. Pereira 2064 (Holotypus). 
gura, coriáceos, obovado-oblongos ou oblongos, glabros e semibrilhantes na face superior e pubescentes, com pilosidade curta e castanho-amarelada na inferior, base obtusa, arredandada ou muitas vezes, retusa; nervura principal impressa na face superior e saliente na inferior, nervuras secundárias ligeiramente impressas na face superior e salientes na inferior. Panícula de $8-17 \mathrm{~cm}$ de comprimento, ferrugíneo-pubescente; bractéolas com 1-1,5 $\mathrm{cm}$ de comprimento, lanceoladas, caducas. Flores com cerca de $1,5 \mathrm{~cm}$ de comprimento; pedicelos curtos, de $2 \mathrm{~mm}$ de comprimento. Cálice campanulảdo, com $6,7 \mathrm{~mm}$ de comprimento, base algo atenuada, externamente seríceo-pubescente e internamente glabro, com exceçăo dos dentes que são pilosos e com $1 \mathrm{~mm}$ de comprimento e triangulares, com ápice subagudo. Corola violácea. Estames de $1 \mathrm{~cm}$ de comprimento, com cerca de $2 / 3$ concrescidos, sendo um livre. Ovário longo-estipitado, pilósulo, com cerca de $1,3 \mathrm{~cm}$ de comprimento; estilete curvo; estigma simples.

TIPOS - BRASIL - Estado da Bahia: entre Lençóis e Itaberaba, 15.IX.1956, Edmundo Pereira 2064 ( $\mathrm{R}$, Holotypus). Estado do Mato Grosso: Cuiabá, s.d. Schwacke 4527 (R, Paratypus) .

DISTRIBUIÇÃo GEOGRÁFiCA - Brasil, nos Estados da Bahia e Mato Grosso.

Andira anthelmia (Vell,) Macbride, in Candolea. 3:26. 1940.

Lumbricidia anthelmia Vell., FI. Flum. 306, 1825; Icon. 7: t. 104. 1831.

Andira enthelminthica Benth., in Ann. Mus. Wien. 2: $108,1838$.

Andira anthelminthica var. ormosioides Benth., in Mart. Fl. Bras. 15(2) : 294. 1859.

Andira anthelmia (Vell.) Toledo, in Arq. Bot. Est. São Paulo, Nov. ser. 2(2) : 29. 1946.

Árvore pequena. Casca cinzenta. Ramos terminais ruivo-tomentosos ou ligeiramente glabros. Estípulas de $4,5-8 \mathrm{~mm}$ de comprimento, geralmente caducas, lanceoladas, acuminadas. Folhas com cerca de $30 \mathrm{~cm}$ de comprimento, pecíolos comuns com $15-20 \mathrm{~cm}$ de comprimento, geralmente denso-tomentosos ruivos; estipelas pequenas; folíolos 9-13, de 5-7,5
$(-10) \mathrm{cm}$ de comprimento e $2,5-3,7 \mathrm{~cm}$ de largura, oboval-elípticos ou oblongos, coriáceos, glabros na face superior e molemente pubescentes na inferior, base arredondada ou largamente cuneada, ápice acuminado, retuso, subarredondado, às vezes, subemarginado, margens recurvas, nervuras salientes na face inferior. Panículas menores que as folhas, ruivo-tomentosas Brácteas e bractéolas caducas. Cálice ligeiramente campanulado, com $6 \mathrm{~mm}$, base obtusa ou ligeiramente atenuada, com dentes curtissimos, subtriangulares, obtusos. Pétalas com o dobro do tamanho do cálice; vexilo orbicular, com a base subcordada, ápice emarginado; asas oblongas, com unha de mais ou menos $1 / 3$ do seu tamanho. Estame vexilar livre até a base; anteras ovado-oblongas. Ovário achatado, vilosos, estípite menor que o cálice; estilete muitas vezes piloso. Drupa oblonga, com cálice obtuso. Semente única.

TIPO - Estado do Rio de Janeiro: "Habitat silvis et campis cum maritimis cum mediterraneis". Vellozo.

NOME VULGAR - "Angelim-de-folha-grande", seg. Bentham (1862) .

DISTRIBUição GEOGRÁFICA - Brasil, nos Estados de Mato Grosso, seg. Bentham (1862) Estacios de Mato Grosso. seg. Bentham (1862), São Paulo, Paraná e Rio de Janeiro.

MATERIAL ESTUDADO - BRASIL - S. IOC., s.d., Riedel 115 (RB 84480); idem, 1824, Riedel 1850 (RB); Sítio Velho, 20.IX.1932, s. col. (RB 54880); Estado de São Paulo: Caraguatatuba, 25.V.1966, J. Mattos 13818 (SP); idem 15.1.1875, Mosén s.n. (R 65858); idem, 20.II.1975, Mosén s.n. ( $R$ 65870); Anhembi, 6.X.195, M. Kuhlmann 393 (SP); Amparo, Monte Alegre, Estação Experimental, 28.H.1942. M. Kuhlmann 282 (SP); Iguape, 3.X.1894, Loefgren \& Edwal s.n. (SP). Estado de Minas Gerais: Conceição do Mato Verde, estrada para Lambari, 17.IX.1919, A. Gehrt s.n. (RB); Belo Horizonte, córrego do Leitão, 13.II.1919, A. Gehrt s.n. (RB); Estado do Rio de Janeiro: restinga da Gávea, 13.VIII.1949, O. Machado s.n. (RB). Estado de Pernambuco: Recife, Dois Irmãos, 12.XII.1948, Dárdano de Andrade Lima 48-126 (RB). 
OBS. - O exemplar RB 75296 corresponde mais exatamente à var. típica.

Andira antheimia (Vell.) Macbride var. gracilis N. Mattos. Loefgrenia 40:3. 1970.

Difere da típica por ter folíolos com $1,4-4.5 \mathrm{~cm}$ de comprimento.

T'IPO - Estado de São Paulo; Limeira, s.d., E. Navarro de Andrade $167(\mathrm{R})$.

DISTRIBUIÇÃo GEOGRÁFICA - Nos Estados de Minas Gerais, Rio de Janeiro e São Paulo.

MATERIAL ESTUDADO - BRASIL - Estado de São Paulo: Limeira, s.d., O. Vecchi s.n. (R 15832); próximo de Mogi-Mirim, no campo, 2.IX.1947, Moysés Kuhlmann 1477 (SP); Tietê, 1.XII.1936, F. C. Hoehne \& A. Gehrt s.n. (SP 37051). Estado de Minas Gerais: Serra do Cipó, km 130, 1100 msm, Minas Palácio, próximo aos capões e formações ciliares, A. Duarte 2276(RB); Belo Horizonte, Vila Nova Horizonte, 8.XII.1932, Mello Barreto 5590 (RB) : Diamantina, margem do Córrego, capoeira; 12.XI.1937, Mello Barreto 10096 (RB); São Joăo D'El Rei, margem do rio Cala-boca, 2.IV.1921, B. Mutz 22120 (RB); Santa Bárbara, Serra do Congo Socco, 12.IV.1933, Mello Barreto 5591 (R). Estado do Rio de Janeiro: Barra da Tijuca, 16.V.1932, J. G. Kuhlmann 2458 (RB); Friburgo, 2.1.1928, Viana Freire 287 (RB)

Andira zehntneri Harms, Fedde Repert. 17:443. 1921.

Árvore com cerca de $10 \mathrm{~m}$ de altura. Ramos terminais esbranquiçados, delgados. Fotha com até 9 folíolos; pecíolo comum de $4,8-5,5 \mathrm{~cm}$ de comprimento, delgado, pubescente, raque pubescente; peciólulo de $3-4 \mathrm{~mm}$ de comprimento; folíolos lanceolados ou oblongos, vilosos, ápice obtuso, agudo ou acuminado, base aguda ou obtusa, folíolos adultos com lâmina de lâmina de $5-8 \mathrm{~cm}$ de comprimento, 2,4-3,2cm de largura, cartácea, glabra na face superior e pubescente na inferilor, nervuras delgadas, impressas na face superior e salientes na inferior. Panícula pouco ramificada, seríceo-pubescente (4-) $10-15 \mathrm{~cm}$ de comprimento; pedúnculo, raque e pedicelos delgados $\mathrm{e}$ seríceo-pubescentes. Cálice com cerca de $5(-6) \mathrm{mm}$ de comprimento, de base obtusa, dentes muito pequenos. Corola roxa, vexilo suborbicular, tênue, seríceo; carena esparsopilosa. Estame vexilar livre até a base. Ovário pubescente. Frutos oblongos, com cerca de $3,4 \mathrm{~cm}$ de comprimento.

TIPO-Estado da Bahia: Zehntner 2097 (M) NOME VULGAR - "Sucupira-preta".

DISTRIBUIÇÃo GEOGRÁFICA - No Brasil, no Estado da Bahia.

MATERIAL ESTUDADO - BRASIL Estado da Bahia: Itabuna, 9-VIII-1964, N. T. Silva 58315 (UB): Boqueirăo, Barra, 13.XI.1922, Zehntner 344 (RB) .

Andira micans Taub., in Harms Fedde Rep. Spc. nov. $17(19-30): 442$. 1921.

Árvore com ramos cilindricos, acizentados Ramos novos subglabros ou glabros, subcilíndricos, cinzento-escuros. Folhas com 9-13 folíolos e com a raque ligeíramente sulcada na face superior e esparsamente adpresso-pubérula. Raque com cerca de $5 \mathrm{~cm}$ de comprimento; pecíolo com cerca de $3 \mathrm{~cm}$, pubérulo; peciólulos pubérulos, com $3-4 \mathrm{~mm}$ de comprimento; lâminas oblongas, oblongo-lanceoladas ou ovadas, esparsamente diminuto-pubérulas ou subglabras na face superior e ligeiramente brilhantes e seríceas na face inferior, $(1,6-) 2-8 \mathrm{~cm}$ de comprimento, $(0,9-) 1-3,5 \mathrm{~cm}$ de largura, base obtusa ou arreciondada, ápice obtuso ou subacuminado, nervuras delgadas, impressas na face superior e salientes na inferior. Inflorescências em panículas com 16 a $18 \mathrm{~cm}$ de comprimento, com raque e pedicelos estriados e achatado-angulosos, pubescentes, com pêlos curtos, adpressos e esbranquiçados. Cálice escuro, com 6-7 $\mathrm{mm}$ de comprimento, com dentes curtos, com cerca de $1 \mathrm{~mm}$ de comprimen. to, largamente obtuso, pubescente ou pubérulo, com pêlos brancos. Corola com vexilo de $12-13 \mathrm{~mm}$ de comprimento, suborbicular, subglabro; estame vexilar livre e os restantes concrescidos, mais ou menos até a terça parte do comprimento. Ovário esparso-piloso, longoestipitado, com estipe com cerca de $4,5-5 \mathrm{~mm}$ de comprimento; óvulos $3-4$; 'estilete curvo e glabro. F. Mus. Neg. 2331. 
TIPO - Estado do Rio de Janeiro, Alto Macahé e Nova Friburgo, 1893: Glaziou 20274 (LE) .

DISTRIBUIÇÃo GEOGRÁFICA - Conhecida apenas da localidade da coleção típica.

obSERVAÇões - No material que recebemos de Leningrado (Herbarium horti Petropolitani), Rússia, havia o nome do coletor como sendo Glazicu 20274, mas procedente de Minas Gerais. Porém, o material-tipo, indicado na diagnose original, consta o nome Glaziou 20274, mas procedente do Rio de Janeiro. Talvez houvesse engano no preenchimento do rótulo do material do herbário de Leningrado, o qual deve ser um isotipo, uma vez que tem o mesmo número do coletor.

Andira macrothyrsa Ducke, in Bol. Técn. I. Agr. Norte. 2:31. 1944.

(Fig. 4)

Árvore com cerca de $40 \mathrm{~m}$ de altura. Ramos terminais fistulosos, angulosos, estriados, escuros, lenticelados, subglabros. Estípulas ausentes, estipelas muito caducas, pequenas e setáceas. Folhas geralmente com $35-40 \mathrm{~cm}$ de comprimento; pecíolos e raque estreitamente canaliculados, glabros ou ligeiramente pilosos. Folíolos 9-13, com pecíolo de $7-12 \mathrm{~mm}$ de comprimento, robustos; lâminas de $5-10 \mathrm{~cm}$ de comprimento e $2,5-4,5 \mathrm{~cm}$ de largura, lanceolado-oblongas, cartáceo-membranáceas ou subcoriáceas, pouco brilhantes na face superior e curtamente pilosas na inferior, reticuladas, ápice moderadamente longo-acuminado, base geralmente obtusa, nervura principal mais ou mencs plana na face superior e saliente na inferior. Panículas terminais, geralmente com $30-50 \mathrm{~cm}$ de comprimento, densamente floridas; pedúnculos e raque angulosos, sulcados, cinzento-tomentosos, com ramificações floridas na metade superior de cada raminho; brácteas caducas, pequenas, subuladas e tomentosas. Flores curtamente pediceladas, aromáticas. Cálice na ântese com cerca de $4 \mathrm{~mm}$ de comprimento e $3 \mathrm{~mm}$ de largura, subcampanulado, verde-escuro (na planta viva), ligeiramente adpresso-piloso; pilosidade cinzenta, 5-partido no ápice, com dentes desiguais. Pétalas com cerca de $7 \mathrm{~mm}$ de comprimento, longo-unguiculadas, glabras, brancas, vexilo pintado de par-

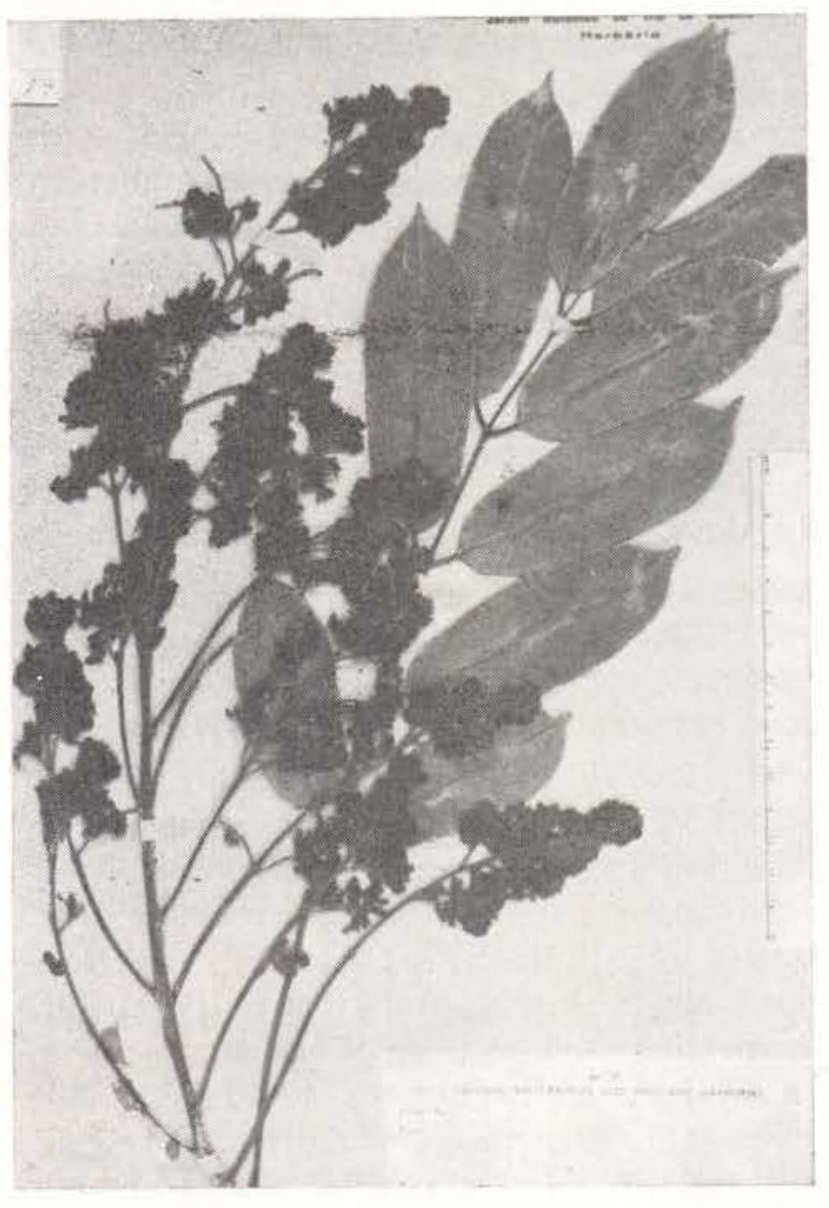

Fig. 4 - Andira macrothyrsa. (A., Ducke 1036).

do-avermelhado. Estames conados até a parte superior, com o vexilar livre. Ovário curto, longo-estipitado, ferrugíneo-acizentado, piloso; estilete branco, subglabro. Drupa de $6 \mathrm{~cm}$ de comprimento e $3-4 \mathrm{~cm}$ de diâmetro.

TIPo - Estado do Amazonas: Esperança, rio Solimões, 22.X.1942, A. Ducke s.n. (R 54579).

DISTRIBUIÇÃo GEOGRÁFICA - Brasil, no Estado do Amazonas.

MATERIAL ESTUDADO - BRASIL - Estado do Amazonas: Esperança, rio Solimões, 22.X.1942, A. Ducke 1036 (RB).

Subsect. Glabratae N. Mattos, Loefgrenia 57:2. 1973. liado.

Ovário glabro, esparso-piloso ou apenas ciTIPO - Andira laurifolia Mart. ex Benth. 
Andira nitida Mart. ex Benth., in Ann. Mus. Wien. 2: 199. 1838.

Árvore com até $8 \mathrm{~m}$ de altura. Ramos lisos, quase glabros. Folíolos 5-9, medindo 5-7,5 $(-9,5)$ $\mathrm{cm}$ de comprimento por $2,5-5,2 \mathrm{~cm}$ de largura, base subcordada ou arredondada, ovado-oblongos, acuminados, coriáceos, glabros ou glabérrimos, brilhantes; nervura principal impressa na face superior e saliente na inferior, nervuras secundárias delgadas e salientes nas duas faces. Estipelas diminutas. Panículas pequenas, laxas. Flores com $9 \mathrm{~mm}$ de comprimento. Cálice urceolado-campanulado, curto, escuro, glabro, às vezes, com pelos esparsos. Corola quase 3 vezes o tamanho do cálice. Ovário glabro ou esparso-piloso.

TIPO - ... "in sabulosis maritimis prope Bahia: Salzmann" (FI) .

DISTRIBUIÇÃo GEOGRÁFICA - Espírito Santo e Bahia, segundo Bentham (1862); Pernambuco e Ceará.

MATERIAL ESTUdADO - BRASIL - Estado de Pernambuco: Recife, Sítio Caçote, 6.X.1949, D. A. Lima 49-313 (R); Olinda, 1.1.1925, Bento Pickel 848 (SP); Estado do Ceará: s. loc., s.d. Freire Alemão e M. de Cysneiros 439 (R); idem, 11.X.1949, s. col. (RB).

Andira marauensis N. Mattos, Loefgrenia 45:1. 1970.

(Fig. 5)

Árvore com $25 \mathrm{~m}$ de altura e até $50 \mathrm{~cm}$ de diâmetro. Ramos delgados, cilíndricos, cinzento-escuros. Ramos novos mais ou menos escuros, esparso-pilosos, com pelos seríceos e pequenos. Folíolos 5: pecíolo $\mathrm{com} 2-3 \mathrm{~cm}$ de comprimento e $0,6 \mathrm{~mm}$ de diâmetro, negros ou castanho-escuros; raque, pecíclo e peciólulo esparso-seríceo-pilosos; peciólulos delgados com cerca de $3 \mathrm{~mm}$ de comprimento; lâminas com $2,4-4,5 \mathrm{~cm}$ de comprimento, $1,3-3,2 \mathrm{~cm}$ de largura, cartáceas, oblongas ou obovado-oblongas, ligeiramente reticuladas, castanho-claras, glab?as e semibrilhantes na face superior e opacas na inferior, margens recurvas, base obtusa ou subarredondadas, ápice emarginado,

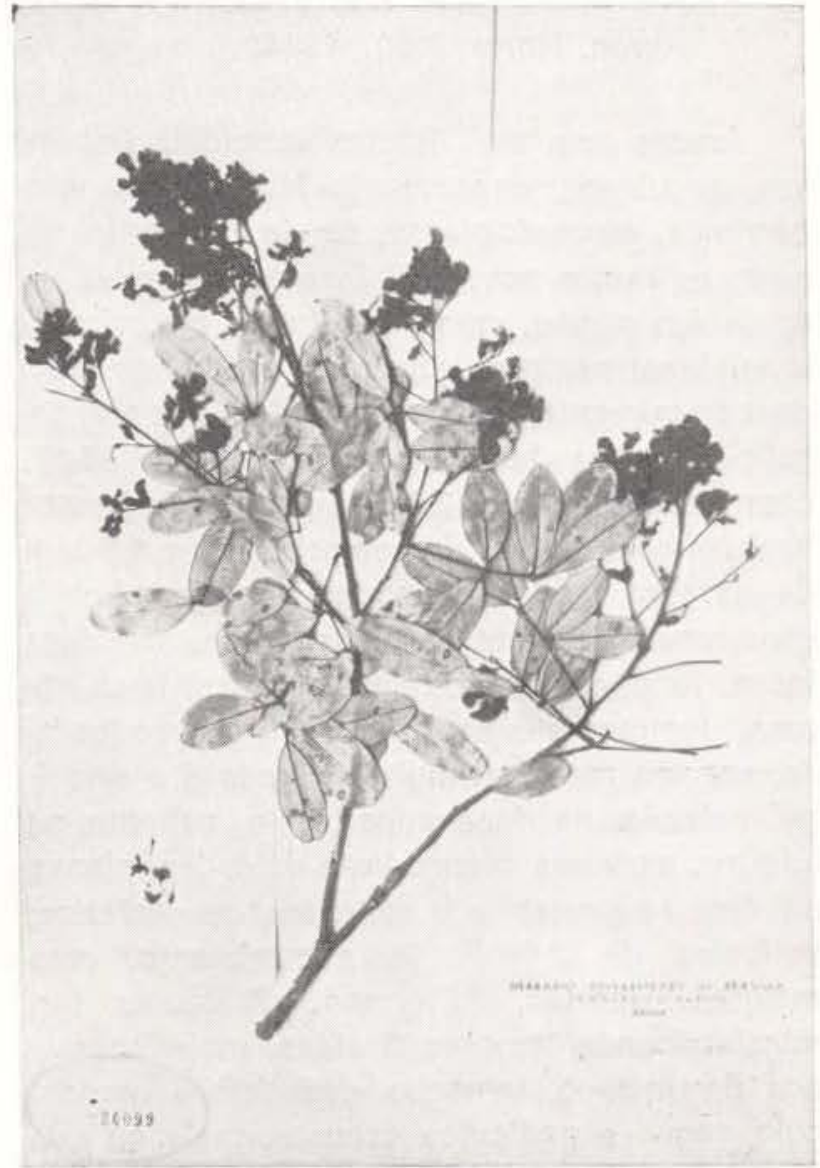

Fig. 5 - Andira marauensis. (Holotypus).

\{xis $-i-1\}$

nervura central impressa na face superior, escura e saliente na infericr, nervuras secundárias quase invisíveis. Inflorescências em panículas terminais, com cerca de $10 \mathrm{~cm}$ de comprimento, multifloras, densifloras: pedúnculo, raque e pedicelos negros ou castanho-escuros, costulados e esparso-pilosos; pedicelos com cerca de $1 \mathrm{~mm}$ de comprimento. Cálice campanulado, com cerca de $3 \mathrm{~mm}$ de comprimento, negro, glabro, salvo no ápice, 5-denticulado. Corola glabra e rosada; estandarte com cerca de $7 \mathrm{~mm}$ de largura, por $7-8 \mathrm{~mm}$ de comprimento. Estames com $8 \mathrm{~mm}$, amarelados (em vivo). Ovário glabrc, estipitado; estilete curvo; estigma sub-capitado.

TiPo - Estado da Bahia: Marau, 18.I.1967, R. P. Belém \& R. S. Pinheiro 3089 (UB).

DISTRIBUição GEOGRÁFICÁ - Conhecida apenas da localidade tipica. 
Andira multistipula Ducke, Bol. Técn. I. Agron. Norte, 2:30. 1944.

Arvore pequena. Ramos terminais fistulosos, angulosos, densamente lenticelados, glabérrimos, cinzento-claros, sendo um tanto escuros os ramos novos. Folhas aglomeradas no ápice dos ramos, com $30-50 \mathrm{~cm}$ de comprimento, glabras; pecíolos com mais ou menos $7 \mathrm{~mm}$ de comprimento, estriados, estreitamente canaliculados na face superior; folíolos 13-17. com peciólulos de $2-4 \mathrm{~mm}$ de comprimento; lâminas com $5-12 \mathrm{~cm}$ de comprimento e $1,5-3 \mathrm{~cm}$ de largura, oblongo-lanceoladas, membranáceas, pouco brilhantes, esverdeadas, nas duas faces, longo-acuminadas, reticuladas, base obtusa, ligeiramente aguda ou obtuso-arredondada, nervura marginal muito delgada e a principal sulcada na face superior e saliente na inferior, nervuras secundárais delgadas, planas na face superior e salientes na inferior; estipelas de $2-6 \mathrm{~mm}$ de comprimento, raro maiores, abertas, filiformes. Panículas terminais abundantemente floridas, mais ou menos do mesmo tamanho das folhas; pedún. culo, raque e pedicelos escuros, mais ou menos achatados, sulcados e angulosos, com pilosidade branco-acizentada, flores subsésseis, ocupando mais ou menos a metade superior de cada ramificação; brácteas caducas, subuladas, cinzento-claras, com até $4 \mathrm{~cm}$ de comprimento, semelhantes às estípulas. Botão floral oblongo, negro, com cerca de $3-5 \mathrm{~mm}$ de comprimento e $2-2,5 \mathrm{~mm}$ de largura, glabro, apenas com tomento cinzento-amarelado nos bordos do cálice e dentes calicinos. Cálice com dentes muito variáveis. Pétalas violáceas, glabras. com cerca de $7-8 \mathrm{~mm}$ de comprimento. Estames conados até mais ou menos $2 / 3$ do tamanho, com exceção do vexilar que é completamente livre. Ovário glabro, curtamente estipitado.

TIPo - Estado do Amazonas: São Paulo de Olivença, 2.XI.1942, A. Ducke 1035 (RB).

DISTRIBUIÇÃo GEOGRÁFICA - Brasil, no Estado do Amazonas.

MATERIAL ESTUDADO - BRASIL - Estado do Amazonas: São Paulo ae Olivença, XII.1945, A. Ducke s.n. (R); Esperança, Igapé da parte baixa do Igarapé, XI.1945, A. Ducke 1822 $(R, R B)$; rio Solimões, próximo ao Município de Tefé, 22.XI.1975, D. Coelho \& C. Mota 621 (INPA).

Andira paniculata Benth., in Ann Wien. Mus. 2:109. 1838.

Árvore de 4-6m de altura. Ramos cinzentos, robustos. Estipelas pequenas com cerca de $2 \mathrm{~mm}$ de comprimento, ruivo-tomentosos. Pecíolo e raque sulcados. Folíolos $11-13$, de $5-7,5(-12) \mathrm{cm}$ de comprimento e $2,5(-6,8) \mathrm{cm}$ de largura, cartáceos, oblongos ou oval-oblongos, pubérulos na face superior e seríceo-pubescentes na inferior, ápice obtuso, base largamente obtusa, arredondada ou cuneada; peciólulo de $1,5-3(-4) \mathrm{mm}$ de comprimento, pubescente. Panículas laxamente piramidais, com cerca de $20 \mathrm{~cm}$ de comprimento, pubescentes, com ramificação delgada. Pedicelos com 1,5-2mm. Flores róseas. Cálice escuro, campanulado, tomentoso, $6-7 \mathrm{~mm}$ de comprimento, com pêlos curtos e adpressos, base aguda, dentes agudos. Pétalas com o dobro do tamanho do cálice, róseo-violáceo; vexilo suborbicular, emarginado; unha um pouco menor que o cálice; asas oblongas, eretas, côncavas; pétalas carenais do tamanho das asas, eretas. Estames claros, com o décimo livre desde a base; anteras escuras, oblongas. Ovário estipitado, glabro (às vezes, esparso-piloso) .

TrPo - ... "in prov. Minarum ad Barbacena et Ponte d'Erva: Pohl".

DISTRIBUIÇÃo GEOGRÁFICA - Brasil, noહ Estados de Minas Gerais e Ceará, seg. Bentham (1862); São Paulo, Distrito Federal, Mato Grosso e Maranhão.

MATERTAL ESTUdAdo - BRASIL - Estado do Ceará: s. loc., Gardner 1839. Estado de Minas Gerais: Chapada de Pirapora, 26.IX.1964. E. P. Heringer 9814 (UB) . Estado de São Paulo: Jeriquara, arredores da cidade, 30.VIII.1963, H. D. Bicalho 7 (SP). Distrito Federal: Brasília, Fazenda Água Limpa, 6.IX.1966, E. P. He ringer 11175 (UB). Estado de Mato Grosso: Norte de Cuiabá, 29.Vlı.1963, Basseć Maguire, Murça Pires e Nilo T. Silva 56403(UB); Chapada da Contagem, 4.IX.1965, H. S. Irwin, R. Souza \& Reis dos Santos 7954 (UB); Parque 
Municipal do Gama, cerca de $20 \mathrm{~km}$ S de Brasília, 31.VIII.1964, H.S. Irwin \& T. R. Sonderstron 5804 (UB). Estado do Maranhão: Loreto. "Ilha de Balsas", Region between the Rios Balsas and Parnaiba - several $\mathrm{km} E$ of main house of Fazenda "Morros", about $35 \mathrm{~km} \mathrm{~S}$ of Loreto. Alt. ca. $300 \mathrm{~m}$, ca. $7^{\circ} \mathrm{S}, 45^{\circ} \mathrm{W}$ place called "Samambaia", 4 may 1962, George Eiten and L. T. Eiten 4513 (SP) .

obSERVAÇÃo - No material de Mato Grosso, Brasilia e São Paulo, o ovário tem alguns pelos, chegąndo até pouco ciliado.

Andira vermifuga Mart. ex Benth., in Ann. Wien. Mus. 2:108. 1838; in Mart. Fl. Bras. 15(1):296.t.113. 1862.

Árvore de $3-6 \mathrm{~m}$ de altura. Ramos novos grossos, suberoso-enrugados. Pecíolo comum de $15-20 \mathrm{~cm}$, ruivo-tomentoso ou glabrescente. Folíolos 9-11, de $5-10 \mathrm{~cm}$ de comprimento e $5-6,3 \mathrm{~cm}$ de largura. grossamente coriáceos, largamente oblongos ou largamente elípticos, glabros na face superior e pubescentes na inferior, nervuras secundárias delgadas, peciólulos curtíssimos, com $1-1,5 \mathrm{~mm}$ de comprimento, grossos. Panículas de $15-30 \mathrm{~cm}$ de comprimento, laxamente piramidais, com ramificação angulosa e ruivo-tomentosa; brácteas caducas, as inferiores ovadas e as superiores menores e agudas; pedicelos $1,5-3 \mathrm{~mm}$ de comprimento; bractéolas pequenas, agudas. Cálice ligeiramente curvo, com cerca de $6 \mathrm{~mm}$ de comprimento, ruivo-tomentoso externamente, base atenuada, dentes largamente triangulares, 2 obtusos e 3 inferiores mais ou menos aglidos. Pétalas com o dobro do tamanho do cálice. róseas; vexilo com estrias violáceas e uma mancha branca no meio, largamente orbicular, emarginado, com unha menor que o cálice; asas oblongas, unha branca; pétalas carenais oblíquas, do tamanho das asas. Estame vexilar livre desde a base; os demais são livres no terço superior. Ovário glabro ou glabérrimo, estipitado, achatado; estilete curvo, filiforme; estigma capitado. Legume ovado-achatado.

TIPO - ... "ad Salgado, et in campis editis Taboleiro provinciae Minas Gerais: Martius" (M).

NOME VULGAR - "Angelim-do-campo".
DISTR:BUIÇÃo GEOGRÁFICA - Brasil, nOS Estados de Minas Gerais e Mato Grosso, seg. Bentham (1862); São Paulo, Bahia, Goiás e Rio de Janeiro.

MATERIAL ESTUDADO - BRASIL - Estado de São Paulo: Município de Mogi-Guaçu, Reserva Florestal (Fazenda Campininha), perto de Pádua Sales. 19.IX.1956, Oswaldo Handro, 615 e 616(SP); Araraquara, Usina Tamôio, Fazenda Santa Joana, 14.IX.1962, G. M. Fellipe 94 (SP). Estado de Mato Grosso: Santana da Chapada, 23.IX.1962, Malme $2371(\mathrm{R})$; São Luiz de Cárcere, IX.1911, Comissão Rondon $4725(\mathrm{R})$; Estado da Bahia: Boqueirão, Santa Rita, X.1912, Zehntner 376 (RB); Estado de Minas Gerais: Rio Novo, s.d., Araujo s.n. (RB 38422); Patos de Minas, 28. VIII.1950, A. Duarte 3282 (RB); Ituiutaba, 16.IX.1950, A. Macedo 2587 (SP). Estado do Rio de Janeiro: Avelar, X.1932, s.col. (R). Estado de Goiás: Cidade Cristalina, cerrado pedregoso, 14.IX.1960, E. P. Heringer 7705 (SP).

Andira laurifolia Benth. var. laurifolia, in: Ann. Wien. Mus. 2: 109. 1838.

Andira humilis Mart. ex Benth., in; Ann. Wien. Mus, 2:109. 1838.

Andira pauciflora Bth., in: Ain. Wien, Mus. 2:109. 1838.

Árvoreta ou arbusto com a parte aérea quase acaule. Raminhos novos mais grossos, com a casca cinzenta, raramente suberosa. Estípulas de $3-4,5 \mathrm{~mm}$ de comprimento, subuladas, cuspidadas; estipelas raramente visíveis. Pecíolo comum com $15-35 \mathrm{~cm}$ de comprimento, giabro ou ligeiramente tomentoso, levemente dilatado na base do último folíolo. As folhas tem $7-17$ folíolos de $7,5-10 \mathrm{~cm}$ de comprimento e $2,5-3,7 \mathrm{~cm}$ de largura, glabros, oblongos, rígido-coriáceos, brilhantes na face superior, mais claros na face inferior, peciolulados. ápice obtuso, base arredondada. Panículas menores que as folhas (raramente iguais), laxas, com ramificação ruiva e ligeiramente tomentosa: pedicelos antes da abertura das flores com 1,5-2mm de comprimento. Cálice com cerca de $4.5 \mathrm{~mm}$ de comprimento, base atenuada com dentes curtos e largamente triangulares; na parte externa, tenuemente pubescente. Péta- 
las com o dobro do tamanho do cálice; vexilo arredondado e emarginado, base largamente truncada; asas oblongas, oblíquas, do tamanho do vexilo; pétalas da carena mais largas que as asas. Estame vexilar livre até a base. Ovário glabro, estípite quase do tamanho do cálice. Drupa ovóidea, não achatada, glabérrima ou glabra. Polh".

TIPO - Estado de Minas Gerais? "Fanado:

$$
\text { NOME VULGAR - "Mata-baratas". }
$$

DISTRIBUIÇÃo GEOGRÁFICA - Brasil nos Estados de Pernambuco e Minas Gerais, seg. Bentham (1862); Rio Grande do Norte, Maranhão, Pernambuco, Goiás, Rio de Janeiro e Sãc Paulo.

OBSERVAÇÃo - Esta espécie é nativa, principalmente, nos cerrados. Sinonimizamos $A$. humilis sob $A$. laurifolia porque, examinando cuidadosamente o material que tivemos em principalmente, o procedente do Herbário de Kew, chegamos à conclusão de que se trata de uma mesma espécie muito variável, tanto no porte como no tamanho e forma dos folíolos, sendo que esta variação pode verificar-se até numa mesma planta.

MATERIAL ESTUDADO - BRASIL - Procedência ignorada, 1822, Riedel 685 (RB); idem, Riedel 2935 (RB); Estado do Paraná: Jaguariaiva, 6.XI.1928, F. C. Hoehne s.n. (SP); Jaguariaiva, 5.XI.1928, F. C. Hoehne s.n. (SP); Estado de São Paulo: Itirapina, $5 \mathrm{~km}$ da Rodovia Washington Luiz, na estrada Itirapina-Rio Claro, 13.IX.1962, G. M. Fellipe 78 (SP); Moji-Guaçu, perto de Pádua Sales, Fazenda Campininha, 3.X.1967, J. Mattos 15059 (SP); idem, 22. IX.1960, G. Eiten \& Liene 2381 (SP); Itú, s.d., A. Russel 15 (SP); Emas, 29.VIII.1943, M. G. Ferri s.n. (SP); Săo Carlos, 17.IX.1938. J. R. Romboust s.n. (SP): Morro Pelado. I.1901, Edwall s.n. (SP); $5 \mathrm{~km}$ a oeste de Jeriquara, 16.III.1964, J. Mattos, 11542 \& H. BicaIho (SP); rio Carapitingui, 15.X.1931, A. Gehrt s.n. (SP); Itapetininga, arredores da cidade, 18. VIII.1960, S. M. Campos 235 (SP); São José do Rio Preto, 9.X.1962, P. M. Camargo \& G. Marinis 24 (SP); Moji-Guaçu, Fazenda Santa Josefina, 28.X.1937, A. V. Oliveira Castro s.n. (SP); Campo Largo, 18.XI.1936, F. C. Hoehne \& A. Gehrt s.n. (SP); Itapetininga, $10 \mathrm{~km}$ NE da Vila Alambari, km 145 da estrada São Paulo-Itapetininga, 2.X.1959, S. M. Campos 69 (SP); Jataí, 8.V.1918, Severo Euclides s.n. (SP); Estado de Minas Gerais: Jaboticatubas, Fazenda do Chagas, 1894, Schwacke 10753 (RB); Sta. Luzia, Lagoa Santa, 4.IX.1933. Mello Barreto 5491 (S P, R); Carandaí, 17.XI.1946, A. Duarte s.n. (RB); serra do Cipó, 16.I.1951, J. G. Kuhlmann \& E. Pereira s.n. (RB) : Morada Nova, 1862, s. col. (R); Ituiutaba, 20.VIII.1944, A. Macedo 442 (SP); Barbacena, VIII.1894, Com. Geogr. Geol. de Minas Gerais $n^{\circ} 50(R)$; Felixlândia, Capão Grande, Bacia das Três Marias, 28.VIII.1959, E. P. Heringer s.n. (RB); Campos da Chapada, Ramal de Montes Claros, J. G. Kuhlmann 230 (RB); serra da Caraça, s.d., Glaziou 15719 (RB); Lagoa Santa, X.IX.1945, Louis Williams \& Vicente Assis 7430 (R); Caeté, Fazenda Geriza, 8.X.1961, Gil Martins Felipe 36 (SP); Ituiutaba, 5.IX.1950, A. Macedo s.n. (SP); Santa Luzia, Lagoa Santa, 14.IX.1933, M. Barreto 5491 (SP); Belo Horizonte, Parque Vera Cruz, 4.X.1932, M. Barreto 5488 (SP), Paraopeba, Horto Florestal, 16.IX.1957, E. P. Heringer 3559 (RB); idem, 12.XII.1958, E. P. Heringer 3555 (SP); Patos de Minas, 21.VIII.1959, A. Duarte 2856 (RB), Estado do Mato Grosso: Santã Ana da Chapada, 26.IX.1902, Malme s.n. (R); Distrito Federal: Brasília, Parque do Guará, 15.X.1962, E. P. Heringer 8627 (HB) . Estado do Maranhão: Grajaú, 13.VIII.1909, M. Arrojado Lisboa S.n. (RB,R); Município de Loreto "Ilha de Balsas", between the rios Balsas and Parnaiba. About $45-50 \mathrm{~km}$ South of Loreto, ca. $7^{\circ} 27^{\prime} \mathrm{S}, 45^{\circ} 15^{\prime} \mathrm{W}$ aolng jeep road between "Santo Estevão" \& "Sítio" (Fazenda Santo Estevão), 3 sept 1963, G. Eiten \& Liene T. Eiten 5457 (SP); Estado de Goiás: Campinas, 2. VIII.1912, Lutzelberg 1548 (RB). Estado do Rio Grande do Norte: Natal, 24.IX.1951, Moacyr Alvarenga 8 (RB). Estado da Bahia: s. col., 30.X.1917, Afrânio Amaral s.n. (SP). Estado de Pernambuco: Taboleiro de També, 30.XI.1951, A. Ducke \& D. A. Lima $39(R)$.

PARAGUAI - Dpt ${ }^{\circ}$ San Pedro, Alto Paraguai, 20.IX.1956, A. L. Woolston 734 (SP). 
Andira laurifolia Bth. var. cordata (N. Mattos) N. Mattos n. comb.

(Fig. 6)

A. humilis Mart, var, cordata N. Mattos, in: Luefgrenia $40: 3.1970$.

Esta variedade se caracteriza por ter folíolos com base cordada.

TIPO - BRASIL - Estado de São Paulo: Itahy, 10.XII. 1929, Jacintha I. de Lima s.n. (RB. Holotypus) .

DISTRIBUIÇÃo GEOGRÁFICA - É conhecido apenas da localidade típica.

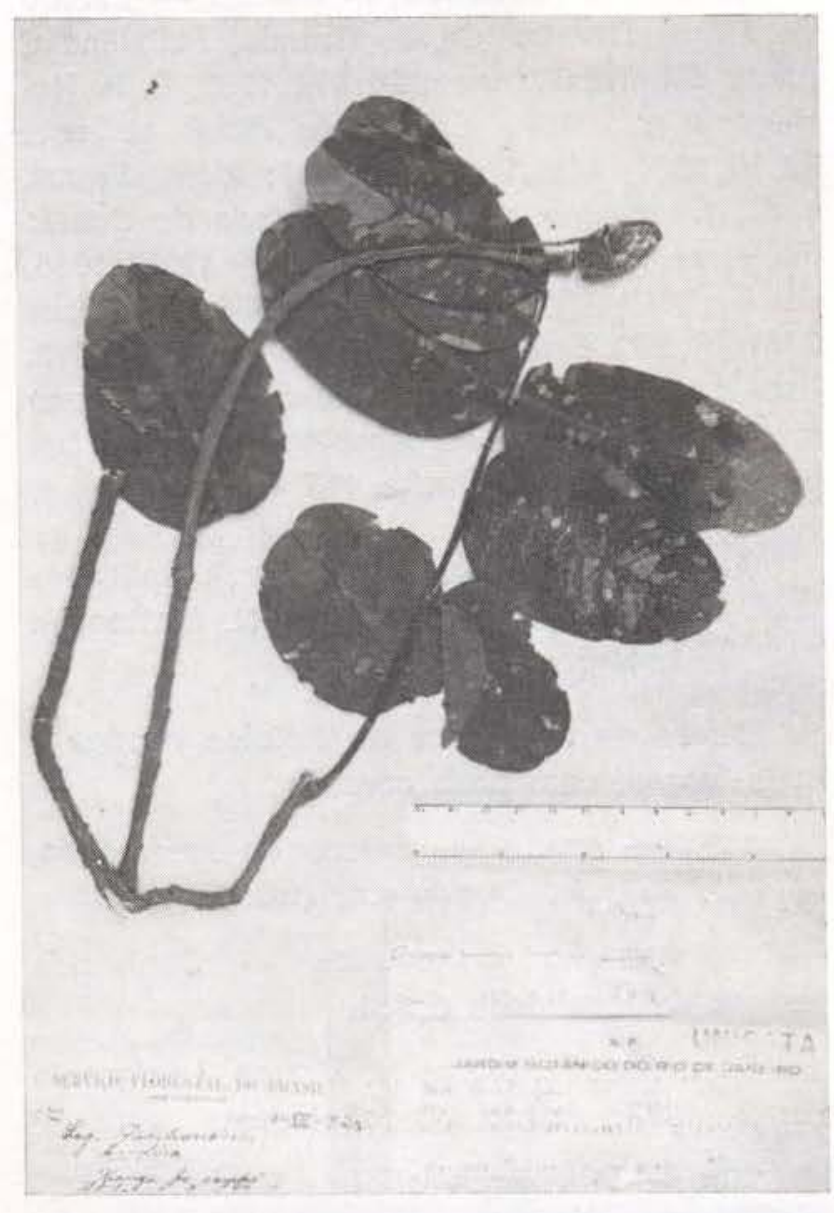

Fig. 6-Andira laurifolia Bth. var. cordata (Holotypus de Andira humilis var. cordata)

Andira inermis (Sw.) H.B.K. var. inermis in Nov. Gen. Sp. Amer. 6:385, 1824.

Goeffroea inermis' Sw., FI. Ind. Occid 3:1255. 1806.

Andira acuminata Benth., in Ann. Wien. Mus. 2:109. 1838 .

Andira grandifolia Guill. et Perr., FI. Seneg. 1:254.
Arvore frondosa, alcançando até $20 \mathrm{~m}$ de altura. Raminhos terminais glabros. Estípulas $1,5-10 \mathrm{~mm}$ de comprimento, às vezes maiores, cartáceas, caducas; estipelas com $1,5-3 \mathrm{~mm}$ de comprimento, setáceas. Pecíolo comum de $15-20 \mathrm{~cm}$ de comprimento. Folíolos 9-15, d6 $5-10 \mathrm{~cm}$ de comprimento, $2,5-3,7 \mathrm{~cm}$ de largura oblongos, glabros, cartáceos ou subcoriáceos, ligeiramente brilhantes na face superior, ápice acuminado, base arredondada ou obtusa; nervura central delgada, impressa na face superior e saliente na inferior, nervuras secundárias quase invisíveis; peciólulo com $1,5-3 \mathrm{~mm}$ de comprimento. Panículas com $15-25 \mathrm{~cm}$ de comprimento, às vezes, menores, tomentosas, densifloras, raramente pouco ramificadas. Flores subsésseis, com pedicelos de até $1 \mathrm{~mm}$ de cơmprimento. Brácteas e bractéolas pequenas, caducas. Cálice com $3-4 \mathrm{~mm}$ de comprimento. tomentoso, largamente campanulado, base obtusa, com 5 dentes pouco distintos. Vexilo orbicular, com ápice emarginado, base geralmente arredondada, unha pouco menor que o cálice; asas obovado-oblongas. Pétalas da carena, curvas, mais largas que as asas. Estame vexilar livre até a base. Ovário glabro, ligeiramente pubescente nas suturas. Legume obliquo, obovóide, com cerca de $3 \mathrm{~cm}$ de comprimento, glabro.

TIPO - Não indicado.

NOMES vUlgares - "Sucupira da várzea", "avineira", "lombrigueira".

DISTRIBUIÇÃo GEOGRÁFICA - América Central; Peru, Guiana, Equador; nos Estados do Amazonas, Pará, Mato Grosso e Território do Amapá, no Brasil.

MATERIAL ESTUDADO - BRASIL - Estado do Pará: Marajó, VIII.1896, J. HUber s.n. (RB); idem, 10.IX.1899, M. Guedes s.n. (RB); Belém, subúrbio, 18.IX.1940, Ducke 599 (R); Belém, Horto do Museu Paraense "Emílio Goeldi". 16. VII.1957, P. Cavalcante 238 (HB); idem, 12. VIII. 1959, M. Kuhlmann \& S. Jimbo 1 (SP) . Estado do Amazonas: Parintins, 20.1.1936. Ducke s.n. (RS); Itacoatiara, 4. VIII.1913, Ducke s.n. (RB). Estado do Mato Grosso: Cuiabá. 24. VIII.1902, O. Malme s.n. (R).

EQUADOR - Prov. Esmeraldas, San Lorenzo, 19. IV. 1943, Elbert L. Lotle, Jr. 6272 (SP). 
Andira inermis (Sw.) H. B. K. var. riedelii Bth., in Mart. FI. Bras. 15(1) :298. 1862. rulos.

Difere da típica por possuir folíolos pubé-

TIPO - Não indicado.

DISTRIBUIÇÃo GEOGRÁfICA - Estado do Mato Grosso.

Andira surinamensis (Bondt) Splitz ex Pulle, in Enum. Plant. Surinam. 229. 1906.

Geoffrea surinamensis Bondt., De cortice Geoffr. Surinam. 13, 1788 .

Geofrrea retusa Poir., Encycl. 8:182. 1808; 3.t.604. fig. 2. 1797.

A. retusa (Poir.) H.B.K., Nov. Gen. et Spec. 6:385. 1824; Bentham, in Mart. FI. Bras. 15(1) : 297. t. 115 . 1862 .

A. retusa H.B.K. var. oblonga Benth., in Mart. Fl. Bras. 15(1) : 297. 1862.

Árvore com até $20 \mathrm{~m}$ de altura (seg. Amshoff, 1939). Ramos novos acastanhados, tomentosos, depois grabiúsculos. Estípulas pequenas, com $3 \mathrm{~mm}$, caducas. Folíolos 9-11, de $6-9 \mathrm{~cm}(-12$, seg. Amshoff, 1939) de comprimento, por $2,8-4,6[-6) \mathrm{cm}$ de largura, oblongos, ovados, cartáceos glabros na face superior e pubérulos na inferior, ápice obtuso, retuso ou emarginado, base arredondada, brilhante na página superior e opacos na inferior, nervura principal impressa na página superior $\mathrm{e}$ saliente na inferior, as secundárias delgadas, planas, impressas ou subimpressas na página superior e salientes na inferior, arqueadas, limbo finamente reticulado. Panículas laxas, tomentosas. Cálice tomentoso, de base aguda com 5 dentes curtos. Pétalas violáceas. Ovário glabro, com $5 \mathrm{~cm}$ de comprimento (seg. Amshoff, 1939) .

TIPO - ... "in Serra Jacobina prov. Bahiensis: Blanchet 3137 [SP, BM. Tipo de $A$. retusa (Poir.) H.B.K.]

NOMES VULGARES - segundo Ducke (1949), esta espécie tem os seguintes nomes populares: "manga-brava", no rio Branco; "Angelim", no litoral pâraense; "morcegueira", "lombrigueira", "andirauchi", "uchirama", no norte do País.
D’̛STRIBUTÇÃo GEOGRÁFICA - Guianas e Trinidad, seg. Amshoff (1939); Amazonas, Pará, Território de Roraima, Ceará, Piauí e Bahia, seg. Bentham (1862) e Ducke (1949).

Obs.: Segundo Ducke (1949), esta espécie é de porte muito variável, apresentando-se como árvore mediana, pequena ou muito grande. Quando isolada no campo, desenvolve copa muito frondosa. É freqủente nos campos de várzea alta ou plantas marginais de raios e lagos.

MATERIAL ESTUdAdo - BRASIL - Estado de Minas Gerais: Capão Grande, Felixlândia, Bacia das Três Marias, 20.VIII.1959, E. P. Heringer s.n. (RB). Estado de Piauí: s. loc., 23. VI.1931, Alencar s.n. (RB); idem, Jiquiri, s.d., Capanema s.n. (RB). Estado do Ceará: Fortaleza, além de Porangaba, 12.III.1955, Ducke 2444 (R); idem 5.III.1955, A. Ducke 2432 (R, SP). Estado do Pará: Óbidos, 7.XII.1913, Ducke s.n. (RB); idem, Santarém, s.d., Spruce s.n. (RB). Estado do Amazonas: Santa Izabel, 10.II.1935, A. Ducke 145 (R).

Andira surinamensis (Bonddt.) Splitz ex Pulle var. ovatifoliolata N. Mattos, in Loefgrenia 37:2. 1973.

Difere da típica por ter folíolos ovados e mais largos, com base cordada.

TIPO - BRASIL - Estado do Pará: Faro, 19.VIII.1907, A. Ducke s.n. (RB 5689).

DISTRIBUIÇão GEOGRÁFICA - Conhecida apenas da localidade típica.

Sect. Paucifoliolatae N. Mattos, Loefgrenia 70: 2. 1973. Folhas $1-3$ folioladas.

TIPO - Andira unifoliolata Ducke.

Andira unifoliolata Ducke, in Arq. Inst. Biol. Veg. 4(1):22. 1938.

Árvore com a parte vegetativa glabra. Folíolos solitários; pecíolos com $1,5-3,0 \mathrm{~cm}$ de comprimento, de base escura e amarelada; peciólulos articulados, grossos, com $3-5 \mathrm{~mm}$ de comprimento; lâminas com $5,2-14,2 \mathrm{~cm}$ de comprimento e $2-6 \mathrm{~cm}$ de largura, lanceolado-oblongas, ligeiramente coriáceas, mais ou menos glaucas, quase da mesma cor nas duas faces, 
brilhantes na face superior e sub-opacas na inferior, base obtusa ou estreitamente arredondada, ápice curto ou longo e gradativamente acuminado, margens tenuemente recurvas nervuras secundárias escendentes. Panículas delgadas, com a raque cinzenta, pouco tomentosa, de $4,0-10,5 \mathrm{~cm}$, pedicelos delgados. Flores de $7 \mathrm{~mm}$, cálice escuro, de $2 \mathrm{~mm}$, vexilo linear e ruivo. Ovário glabro. Drupa com 2,5-3,0cm, globosos ou elipsóides com $4 \mathrm{~cm}$ no diâmetro maior e $3 \mathrm{~cm}$ no menor (seg. Ducke, 1938).

тTPO - Estado de Amazonas: Manaus, estrada do Aleixo, 3.III.1937, A. Ducke s.n. (RB).

DISTRIBUIÇÃo GEOGRÁFica - Brasil, no Estado do Amazonas.

MATERIAL ESTUdAdo - BRASIL - Estado do Amazonas: Manaus, Estrada do Aleixo, 18.II.1941, A. Ducke 674 (R, SP); Estrada Manaus-Itacoatiara, $\mathrm{km} \mathrm{27,} \mathrm{Reserva} \mathrm{Florestal}$ Ducke, 24.X.1968, J. Aluísio 226 (INPA); idem, 7.III.1968, W. Rodrigues, L. Coelho \& D. Coelho 8477 (INPA); idem, 9.III.1965, W. Rodrigues \& Osmarino 6888 (INPA); idem, 17. VII. 1964, W. Rodrigues \& A. Loreiro 5953 (INPA); idem, 19.VIII.1968, J. Aluísio s.n. (INPA 21.366); idem, 1966, W. Rodrigues \& D. Coelho 7554 (INPA); idem, Fenológico, 24.V.1966, W. Rodrigues \& D. Coelho 7863 (INPA); idem, 22.III.1968, W. Rodrigues \& Osmarino 8472 (INPA); idem, 24.X.1968, J. Aluísio 224 (INPA); rio Castanho, margem direita, estrada para o Careiro, 10.III.1972, M. Silva et al. 373 (INPA); idem, $\mathrm{km} \mathrm{133,}$ 7.VII.1975, O. P. Monteiro \& F. Mello s.n. (INPA 50.058).

Obs.; Os exemplares de J. Aluísio 226 e J. Aluísio s.n. (INPA 21.366), diferem da típica por apresentarem folíolos largamente oblongos ou largamente ovado-oblongos.

Andira trifoliolata Ducke, in Arq. Inst. Biol. Veg. 4(1):22. 1938.

Arvoreta com a parte vegetativa toda glabriúscula. Folhas constantemente trifolioladas; pecíolo comum $2,5-5 \mathrm{~cm}$ de comprimento; peciốlulos dos folíolos laterais com $1-2 \mathrm{~mm}$ de comprimento, do foliolo terminal com $4-8 \mathrm{~mm}$ de comprimento, articulado; estipelas de comprimento, setáceas, muito caducas; folíolos com $6-13 \mathrm{~cm}$ de comprimento e $3-5 \mathrm{~cm}$ de largura, ovado-oblongos, ligeiramente coriáceos, quase a mesma cor nas duas faces, subrecurvas nas margens, nervuras pouco visíveis na face superior e ligeiramente salientes na inferior. Panículas com pedicelos curtíssimos, com flores maiores que em $A$. unifoliolata. Cálice com até $4 \mathrm{~mm}$ de comprimento. Ovário glabro; estilete glabro, seg. Ducke (1938).

TIPO - "Ad flumen Curicuriary inferius ripis altis, 20.11.1956, fl. com foliis maturis, A. Ducke s.n." (RB).

DISTRIBUIÇÃo GEOGRÁFICA - Brasil, no Estado do Amazonas.

MATERIAL ESTUDADO - BRASIL - Estado do Amazonas: Circa Barcelos, 14.1I.1905, A. Ducke s.n. (RB); Manaus, 18.II.1941, A. Ducke 674 (SP); Estrada Manaus-Porto Velho, 20. VII.1972, M. Silva et al. 797 (INPA).

Andira bahiensis N. Mattos, Loefgrenia 45: 1. 1970.

(Fig. 7)

Árvore com $6 \mathrm{~m}$ de altura. Ramos cilíndricos, cinzentos; raminhos terminais sub-cilíndricos, pilosos. Folhas, 9-folioladas; estipelas com cerca de $1,5 \mathrm{~cm}$ de comprimento, pubescentes; pecíolos de $2,5-3,5 \mathrm{~cm}$ de comprimento, raque com $4-9 \mathrm{~cm}$ de comprimento; peciólulos de $1-2 \mathrm{~mm}$ de comprimento, pilosos; laminas dos folílos $2,0-4,5 \mathrm{~cm}$ de comprimento e $0,7-2,0$ $\mathrm{cm}$ de largura, cartáceas, oblongas, obovadooblongas ou oblongo-lanceoladas, pubérulas, subopacas e cinzento-acastanhadas na face superior e pubescentes e ruivo-acastanhadas na inferior, base obtusa ou sub-arredondada, ápice emarginado, muitas vezes sub-recurvo, margens recurvas, nervuras impressas na face superior e salientes na inferior. Panículas cerca de $8 \mathrm{~cm}$ de comprimento, delgadas, ruivas, bubescentes; bractéolas com cerca de $1,5 \mathrm{~mm}$ de comprimento, lanceadas, caducas. Flores de 1,9-2,2cm de comprimento, rosadas (seg. col.); pedicelos com cerca de $2 \mathrm{~mm}$ de comprimento; cálice campanulado, 5-dentado, $6-7 \mathrm{~mm}$ de comprimento, adpresso-piloso externamente, glabro internamente, com dentes triangular-subarredondados, com até $1 \mathrm{~mm}$ de comprimento; corola com até $1,9 \mathrm{~cm}$, glabra, unha com cerca 


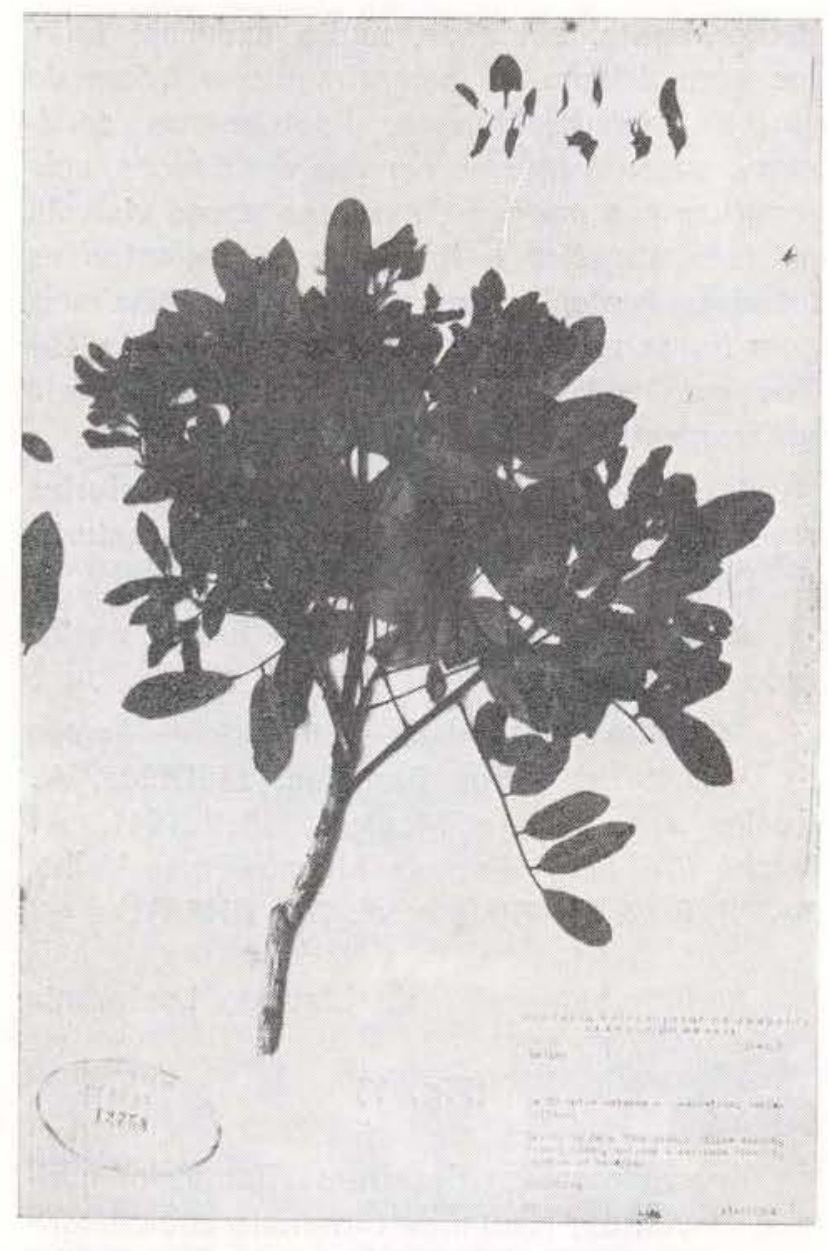

Fig. 7 - Andira bahiensis. (Holotypus).

de $0,5 \mathrm{~cm}$ de comprimento; estames em quase 2/3 concrescidos; ovário denso e adpresso-pubescente com cerca de $3 \mathrm{~mm}$ de comprimento, estipitado, com estilete pubescente e estigma subcapitado.

TIPO - Estado da Bahia; km 80 entre Betanha e Canavieiras, 13.VIII.1964, N. T. Silva 58414 (UB) .

NOME VULGAR - "Angelim".

DISTRIBUIÇÃo GEOGRÁFICA - Conhecida apenas da localidade típica.

UTILIDADES - Pode ser utilizada como ornamental nos parques e jardins. Sua madeira pode ser empregada para moirões e lenha.

\section{AGRADECIMENTOS}

Pelo empréstimo do material botânico, agradecemos aos Srs. Diretores e Chefes dos seguintes herbários: Herbário do Jardim Botânico do Rio de Janeiro (RB); Herbário do Museu Nacional ( $R$ ); Herbário do Museu de Munique, Alemanha (M); Herbário da Academia de Ciências da U.R.S.S. (LE); New York Botanical Garden (NY); Herbário da Universidade de Brasília (UB); Herbário Barbosa Rodrigues (HBR); Herbário Bradeanum (HB); Herbário do Instituto Nacional de Pesquisas da Amazônia (INPA).

\section{SUMMMARY}

In this paper, the autor makes a study about the brazilian species of the genus Andira, group of plants known by popular name of "Angelim". In Brazil, there are 27 species and 7 varieties, but the greatest number of them belongs brazilian Amazonia and the number of the species decreases to the south states. In Santa Catarina State, we found only a species and none species in Rio Grande do Sul State. The author placed in sinonimy two species and gives key for the species and varieties.

\section{BIBLIOGRAFIA}

AMSHOFF, G.H.

1939 - Papilionaceae, In Pulle, Flora of Suriname, Amsterdam 2(2): 1.127 .

BARROSO, G.M.

1965 - Leguminosas da Guanabara. Rio de Janeiro Args. Jard. Bot. Rio de Janeiro, 18: 154-57.

BENTHAM, G.

1862 - Papilionaceae. In Mart. Fl. Bras. 15(1) : 291-9. Monachii.

BRENER, J.P.

1965 - The Geographical Relationship of the Genera of Leguminosae in Tropical. Florença, Webbia $19(2):$ 545-78.

Brocadet, A.P.

1921 - Plantas Utiles du Brésil. Paris, p. 34.

BURKART, A.

1949 - La posición sistemática del "Chañar" y las especies del género Geoffroea (Leguminosae-Dalbergieae.) Buenos Aires, Darwiniana $9(1): 9-23$.

1952 - Las Leguminosas Argentinas Silvestres y Cultivadas. 2.a ed. Buenos Aires, p. 240.

CORRÊA, M.P.

1926 - Dicionário das plantas úteis do Brasil e das exóticas cultivadas. Rio dé Janeiro, Impr. Nac. 1: 11821. 
de Candolle, A.P.

1825 - Leguminosae. In Prodromus Systematis Naturalis Regni Vegetabilis, Paris, 2: 93-524.

DUCKE, A.

1936 - Notes on the Species of Hymenolobium: Giant trees of Brasilian Amazenia. New Hoven, Tropical Wools, $47: 1-6$.

1949 - As Leguminosas da Amazônia Brasileira. 2." ed. Belém, Bol. Téc. Inst. Agr. Norte $18: 200-202$.

LAMARK, J.B.

1783 - Encyclopédie Methódique. Paris.

LANE, $\mathbf{F}$,

1968 - Comunicação verbal.
LOEFGREN, A.

1917 - Manual das Familias Naturais Fanerogâmicas. Rio de Janeiro, Impr. Nac. p. 43-5.

MACBRIDE, J.F.

1943 - Leguminosae. In Pulle Flora of Perú. Chicago, Field Mus. Nat. Hist. ser. $1:$ III(1) : 1.507.

PitTier, $\mathrm{H}$.

1944 - Leguminosas de Venezuela - I. Papilionáceas. Caracas, Bol. Técn. Min. Agr. y Cria $5: 1-180$.

TOLEDO, J.F.

1946 - Observaçōes críticas sobre nomes de algumas plantas brasileiras. São Paulo, Args. Bot. Est, S. Paulo. Nov. sér, 2(2):29.

(Aceito para publicaçăo em $17 / 12 / 78$ ) 


\section{INDICE ANALITICO}

Pág.

Andira

$241,242,243$

Andira acuminata $\ldots \ldots \ldots \ldots \ldots \ldots \ldots \ldots \ldots \ldots \ldots \ldots \ldots \ldots \ldots, 261$

Andira anthelmia ........... 242, 243, 245, 254, 255

Andira anthelmia var. gracilis ............ 245

Andira anthelminthica ..................... 254

Andira anthelminthica var. ormosioides ....... 254

Andira bahiensis ................... 246, 263

Andira cuyabensis ..............242, 243, 244, 249

Andira fraxinifolia ............... 242,243,244, 250

Andira fraxinifolia var. lanceata ......... 244, 251

Andira frondosa ................. 243, 245, 252

Andira frondosa var. Iongifoliolata ....... 245, 252

Andira grandifolia $\ldots \ldots \ldots \ldots \ldots \ldots \ldots \ldots \ldots . \ldots \ldots, 261$

Andira handroana $\ldots \ldots \ldots \ldots \ldots \ldots \ldots . . \ldots 245,253$

Andira humilis $\ldots \ldots \ldots \ldots \ldots \ldots \ldots \ldots \ldots . \ldots \ldots 242, \quad 259$

Andira humilis var. cordata ................ 261

Andira inermis ...............243, 246, 261, 262

Andira inermis var. riedeli $\ldots \ldots \ldots \ldots \ldots \ldots .246$

Andira kuhlmannii .................. 243,244, 246

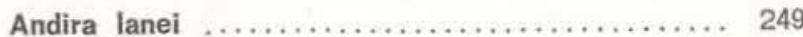

Andira laurifolia .............. 243, 246, 256, 259

Andira laurifolia var. cordata ............ 246, 261

Andira legalis ............. 242, 243, 244, 246, 248

Andira legalis var. bahiensis .............. 248

Andira macrothyrsa ................ 243, 245, 256

Andira marauensis ....................... 257

Andira micans ...................... 243, 255

Andira micrantha $\ldots \ldots \ldots \ldots \ldots \ldots \ldots, 243,244,247$

Andira multistipula $\ldots \ldots \ldots \ldots \ldots \ldots \ldots 243,245,258$

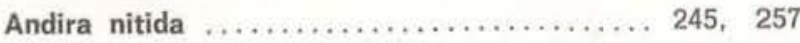

Andira paniculata $\ldots \ldots \ldots \ldots \ldots \ldots \ldots .243 \quad 245,258$

Andira parvifolia .............. 242, 243, 244, 251

Andira parviflora .............. 242, 243, 245, 251

Andira pauciflora ........................ 259

Andira pernambucensis ................ 245, 252

Andira pisonis ............... 242, 243, 244, 249
Pảg.

Andira pisonis var. emarginata ......... 244, 250

Andira pisonis var. puberula ............ 244, 250

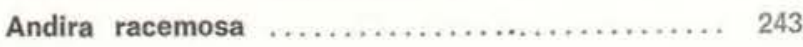

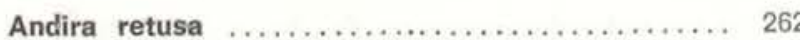

Andira retusa var. oblonga $\ldots \ldots \ldots \ldots \ldots \ldots . .262$

Andira stipulacea $\ldots \ldots \ldots \ldots \ldots \ldots \ldots \ldots \ldots .248$

Andira stipulacea var. bahiensis ............ 248

Andira surinamensis $\ldots \ldots \ldots \ldots \ldots \ldots .243,246,262$

Andira surinamensis var. ovatifolia .......... 262

Andira trifoliolata .................... 246, 263

Andira unifoliolata ............. 242, 243, 246, 262

Andira vermifuga $\ldots \ldots \ldots \ldots \ldots \ldots 242,243,246,259$

Andira villosa ..................... 243, 244, 246

Andira zehntneri ..................... 245, 255

Ferreirea spectabilis ..................... 242

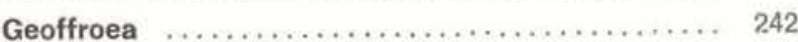

Geoffroea inermis ................... 242, 261

Geoffroea retusa ....................... 262

Geoffroea surinamensis ............... 243, 262

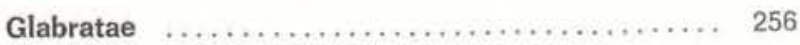

Hymenolobium ......................... 242

Hymenolobium elatum ..................... 242

Hymenolobium excelsum .................. 242

Hymenolobium modestum ................... 242

Hymenolobium nitidum ..................... 242

Hymenolobium petraeum $\ldots \ldots \ldots \ldots \ldots \ldots \ldots .242$

Hymenolobium pulcherrimum ................. 242

Lumbricidia $\ldots \ldots \ldots \ldots \ldots \ldots \ldots \ldots \ldots . \ldots . \ldots . . \ldots 244,246$

Lumbricidia anthelmia .................... 254

Lumbricidia legalis ................. 246, 248

Paucifoliolatae ............................ 262

Peraltea erythrinaefolia .................... 242

Platycianus regnellii $\ldots \ldots \ldots \ldots \ldots \ldots \ldots \ldots \ldots . \ldots \ldots \ldots \ldots, 242$

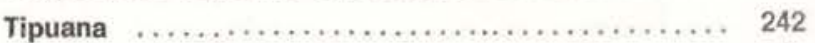

Vataireopsis araroba ...................... 242

Vouacapoua legalis $\ldots \ldots \ldots \ldots \ldots \ldots \ldots \ldots \ldots, 248$ 